
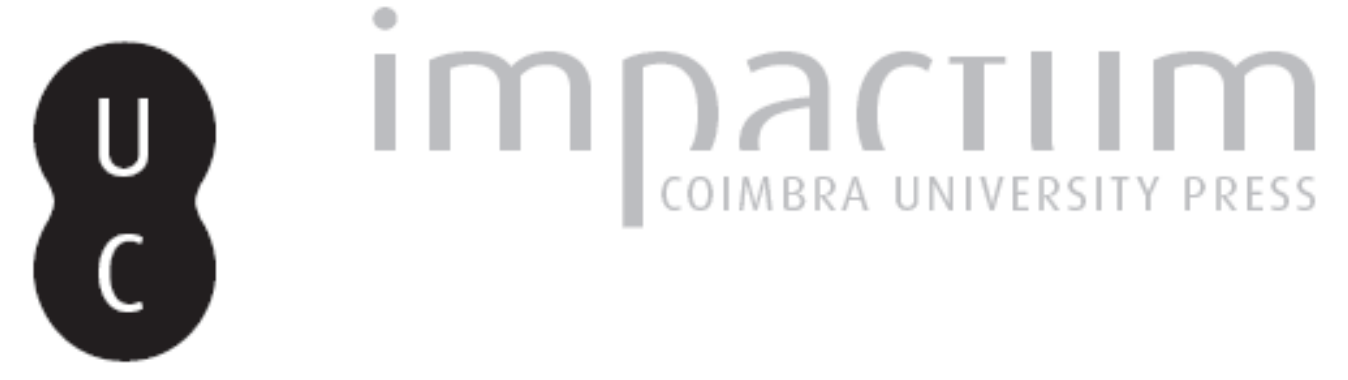

\title{
“J'ai éprouvé que vous m'étie z moins cher que ma passi on”: paixão e identificação projectiva nas "Lettres Portugaises"
}

Autor(es): $\quad$ Pires, Edmundo Balsemão

Publicado por: $\begin{aligned} & \text { Faculdade de Letras da Universidade de Coimbra, Instituto de Estudos } \\ & \text { Filosóficos }\end{aligned}$

URL

persistente:

DOI: $\quad$ DOI:http://dx.doi.org/10.14195/0872-0851_41_2

Accessed : $\quad$ 26-Apr-2023 14:09:20

A navegação consulta e descarregamento dos títulos inseridos nas Bibliotecas Digitais UC Digitalis, UC Pombalina e UC Impactum, pressupõem a aceitação plena e sem reservas dos Termos e Condições de Uso destas Bibliotecas Digitais, disponíveis em https://digitalis.uc.pt/pt-pt/termos.

Conforme exposto nos referidos Termos e Condições de Uso, o descarregamento de títulos de acesso restrito requer uma licença válida de autorização devendo o utilizador aceder ao(s) documento(s) a partir de um endereço de IP da instituição detentora da supramencionada licença.

Ao utilizador é apenas permitido o descarregamento para uso pessoal, pelo que o emprego do(s) título(s) descarregado(s) para outro fim, designadamente comercial, carece de autorização do respetivo autor ou editor da obra.

Na medida em que todas as obras da UC Digitalis se encontram protegidas pelo Código do Direito de Autor e Direitos Conexos e demais legislação aplicável, toda a cópia, parcial ou total, deste documento, nos casos em que é legalmente admitida, deverá conter ou fazer-se acompanhar por este aviso.

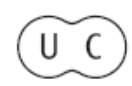




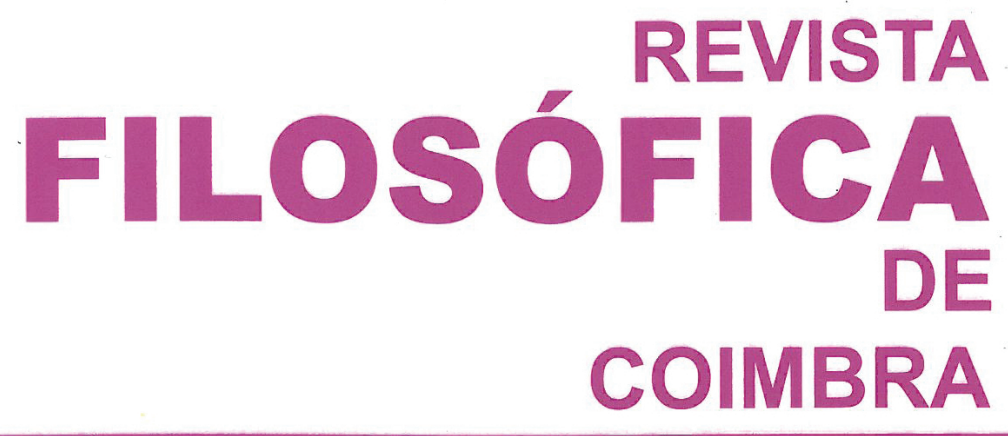

vol. 21 - número 41 - março 2012

vol. 21 - número 41 - março 2012

Fundação Eng. António de Almeida

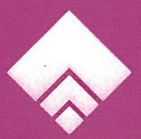




\section{“J'AI ÉPROUVÉ QUE VOUS M'ÉTIEZ MOINS CHER QUE MA PASSION" - PAIXÃO E IDENTIFICAÇÃO PROJECTIVA NAS "LETTRES PORTUGAISES"}

\section{EDMUNDO BALSEMÃO PIRES*}

Sumário: Neste trabalho proponho um esboço de uma descrição sistémica do acoplamento estrutural entre sistemas psíquicos e comunicativos no caso do "amor como paixão" com base num "estudo de caso".

A descrição desenvolve-se com uma atenção especial aos seguintes aspectos.

* A emergência da semântica do "amor como paixão" e a importância de uma observação comunicativa das emoções nas relações íntimas;

** os temas nascidos da diferenciação semântica do amor e a observação das emoções nas relações íntimas: a distinção entre as emoções duradouras adequadas à constituição da intimidade familiar e o amor decepcionante ou as paixões "perversas";

*** a "identificação projectiva" nas relações íntimas como um modelo comportamental que reflecte a imagem psíquica de um acoplamento estrutural entre formas da consciência e formas da comunicação e como um mecanismo responsável pela ultrapassagem das desilusões e pela rejeição das propensões "perversas".

Com o sentido de sistematizar a observação da vida emocional e a observação da individualidade dos membros da família e a intimidade, a sociedade moderna gerou temas da comunicação e uma semântica que vai desde a constituição de alguns géneros literários (como a novela) até às tipologias psiquiátricas dos desvios, as concepções ingénuas ou eruditas sobre a natureza dos sexos e o discurso feminista sobre a igualdade do género. $\mathrm{O}$ conceito moderno de intimidade é um dos aspectos da evolução sócio-cultural que combina estas fontes de observações,

* Departamento de Filosofia, Comunicação e Informação (Faculdade de Letras da Universidade de Coimbra).

Este estudo insere-se no conjunto dos trabalhos de investigação do Grupo de investigação dedicado ao tema da "Individuação da Sociedade Moderna" da unidade de investigação L. I. F. - F. C. T. da Universidade de Coimbra. A sua forma actual evoluiu de uma base escrita inicial destinada a ser objecto de apresentação oral em dois encontros internacionais um fora do país, Croácia, Dubrovnik, e outro em Portugal, Coimbra (2011). 
a semântica e as correspondentes descrições.

Vou examinar alguns aspectos da semântica do "amor como paixão" na História da Literatura tomando as cartas de amor atribuídas à portuguesa Soror Mariana Alcoforado (1640-1723) como um "caso de estudo". Mas a finalidade principal destas notas é a de fornecer uma descrição teórica apropriada do acoplamento estrutural dos sistemas psíquicos e da comunicação no amor mediante a clarificação do mecanismo da "identificação projectiva".

Palavras chave: "amor como paixão", "Lettres Portugaises", identificação, "identificação projectiva", comunicação epistolar, intimidade, acoplamento estrutural.

\begin{abstract}
In this paper, I will propose a sketch of a systemic description of the structural coupling between psychic and social systems in the case of "love as passion" grounded on a "case study".

The description entails special concerns with the connections between the following aspects.

* The emergence of the semantics of "love as passion" and the importance of a communicative observation of emotions in intimate relations;

** the issues raised by the semantic differentiation of love and the observation of emotions in intimate relations: the love capable of enduring emotions suitable to the constitution of a family and the deceptive love or the "perverse" passions;

*** the "projective identification" in intimate relations as a behavioural pattern reflecting a coupling between psychic and communicative elements of the intimate communication and as a mechanism responsible for the overcoming of deceptions and for the rejection of deceptive or "perverse" propensities.

In order to systematize the observation of the emotional life and the observation of the individuality of family members and intimacy, modern society generated communicative "themes" and semantics, going from some literary genres (the novel) to the typologies referring to deviations of the psychiatric discourse, the naïve or erudite conceptions on the nature of the sexes or the feminist discourse on the equality of gender. The modern concept of intimacy is one of the effects of the historical evolution blending these sources of observations, semantics and descriptions.

I will scrutinize the aspects of the semantics of "love as passion" in the History of Literature taking the love letters attributed to the Portuguese nun Soror Mariana Alcoforado (1640-1723) as an empirical "case-study". But the main objective of these notes is the theoretical description of the structural coupling of psychic systems and communication in love through the examination of the mechanism of the "projective identification".
\end{abstract}

Key words: "love as passion", "Lettres Portugaises", identification, "projective identification", epistolary communication, intimacy, structural coupling. C'est l'amour qui doit régner sur toutes les fonctions de notre âme 


\section{Identificação e Individuação}

Um dos temas mais exigentes do pensamento filosófico clássico foi seguramente o do amor. Entender o alcance das suas exigências no contexto da modernidade significa não poder evitar as relações difíceis de cingir conceptualmente que ligam amor e subjectividade, amor e paixão, amor e pulsões ou amor e individualidade. Em virtude dos problemas de diferenciação e de ligamento dos níveis orgânico-somático, psíquico e comunicativo de conceitos como o de desejo, de amor ou de paixão nas concepções modernas posteriores à concepção romântica da "natureza humana" esses temas foram suscitados num confronto privilegiado com a Psicanálise, a cujas lições regresso aqui no ponto de partida do estudo de um caso exemplar de "amor-paixão" datado do século XVII e imaginado num espaço territorial que definiríamos como "português". Quero referir-me à paixão narrada num texto literário com um valor ficcional inequívoco e sem qualquer pretensão de exercício teórico sobre o seu próprio "objecto": as Cartas Portuguesas.

$\mathrm{Na}$ fase inicial de formulação da sua teoria das pulsões, Freud pensou que era possível reduzir os fenómenos da vida psíquica ao princípio conservador do "princípio do prazer" que era um princípio económico, baseado na ideia de um equilíbrio homeostático entre a fonte de prazer e a capacidade do sistema psíquico para suportar a dor e o "princípio da realidade", dependente das determinações da percepção e da capacidade adaptativa do sujeito ao seu meio. O que define no plano do conteúdo o princípio do prazer é o nexo causal entre o aparelho psíquico e o meio ambiente, daí a importância concedida à libido interpretada como energia sexual com forte referência orgânica e somática nos seus primeiros trabalhos.

Até aqui o aparelho psíquico era todo ele concebido como estando atravessado por pulsões extra-psíquicas que escolhiam determinados objectos do mundo externo para investimento pulsional.

$\mathrm{Na}$ explicação inicial Freud sustentava a ideia de que o aparelho psíquico obedecia ao "princípio da constância". Este princípio homeostático permitia explicar como é que o aparelho psíquico liberta a energia que não consegue reservar nem absorver, de modo a manter sempre um mesmo nível de energia constante. O que Freud também chamava "princípio de Nirvana" dizia respeito a esta tendência para produzir um equilíbrio da tensão interior e reduzir toda a fonte de perturbação externa.

O que realiza a transição desta primeira versão da sua teoria das pulsões, de inspiração termodinâmica, para as ideias ulteriores é o artigo sobre o "narcisismo" publicado em 1914.

O caminho ulterior da teoria freudiana das pulsões pode ser recons- 
-truído nos textos mais importantes, que vão desde Luto e Melancolia (1915), que contém uma análise do sadismo, a concepção da agressividade do super-ego contra o eu e as teses sobre a regressão narcísica, passando pelas Considerações actuais sobre a guerra e sobre a morte (1915), até ao Para além do princípio do prazer (1920). Neste trabalho reuniam-se reflexões sobre traumas de guerra, sobre auto-punição e sonhos de auto-punição e sobre a compulsão para a repetição. Freud continua a explorar o tema herdado de Fechner do aparelho psíquico como acumulador/aliviador de tensões e regulador da energia pulsional.

Quando Freud ficciona a função psíquica da "pulsão da morte" o próprio conceito de desejo sofre uma alteração fundamental. Um dos problemas que está em jogo na noção freudiana de "pulsão da morte" é o da posição no aparelho psíquico de um desejo que não possui articulação com nada de captável pela percepção, de empiricamente reconhecível, ou seja, a revelação da tendência do psiquismo para romper a coincidência entre a percepção da realidade e a pulsão "adequada" ao ser externo do ob-jecto. A morte posiciona-se para o sujeito, neste sentido, como o objecto absoluto. A "pulsão da morte" revela-nos como o desejo do inconsciente é o desejo de um objecto para sempre ausente.

Em Para além do Princípio de Prazer (1920) Freud fundava a sua teoria das pulsões numa nova convicção, que lhe advinha da constatação do retorno das experiências penosas nos sonhos pós-traumáticos. Nisto ele fundou a sua intuição segundo a qual o objectivo de toda a vida é a morte. Esta ideia está articulada com outra intuição, aquela segundo a qual existe uma pulsão com um valor reintegrador naquela realidade a que chamou o "anorgânico".

Na época de Para além do Princípio de Prazer predominava a necessidade de encontrar resposta para a compulsão de repetição e para determinados comportamentos em que os indivíduos pareciam ser conduzidos, como que por fatalidade, a precipitar acções nefastas umas atrás de outras. Para o fim da divisão VI deste trabalho, o autor aproximava a sua hipótese explicativa da "pulsão de morte" de um regresso ao anorgânico da teoria platónica do andrógino do Banquete" .

A ideia de uma unidade primitiva que se desmembra em vários fragmentos para nestes últimos dar lugar a uma nostalgia da unidade primitiva é analogada com a forma de reintegração do psiquismo numa unidade mais primitiva da natureza, graças ao trabalho da pulsão da morte, que é

${ }^{1}$ S. Freud, "Beyond the Pleasure Principle" in Idem, The Standard Edition of the Complete Works of Sigmund Freud (ed. J. Strachey, A. Freud, A. Strachey e A. Tyson), vol. XVIII, London, 1955, pp. 57-58. 
então designada por "pulsão da reunificação".

Quando Freud num dos estudos metapsicológicos sobre "As pulsões e o destino das pulsões" $(1915)^{2}$ referia a necessidade de uma definição mais precisa da pulsão, partia de um tema aberto desde a Filosofa Platónica com um valor semântico muito amplo e cuja difusão terminológica perdurou até ao século XIX numa literatura que não se reduziu à Filosofia.

Graças a uma exigente restrição ao campo psíquico, Freud modificou o significado do que ele designava por "pulsão psíquica" ao afirmar que esta não se podia confundir com a excitação fisiológica ou com um simples reflexo de natureza instintiva. A tese resultante sustentava que a excitação pulsional própria da pulsão psíquica não provinha do "mundo exterior" mas do "interior" do próprio aparelho psíquico. A existência de uma força interior que impele o sujeito em determinada direcção, a fazer determinadas coisas, faz com que se tenha de considerar a pulsão "psíquica" como oriunda de um "mundo interior" e seja por isso justificado um valor opositivo, um diferencial, entre "interior" e "exterior". É evidente nos esforços do pai da Psicanálise a precisão de uma fronteira entre o que pode ser visto como o lado biológico e o lado psíquico da pulsão. É isso que explica a diferença no Homem entre a pulsão psíquica, os instintos e as necessidades.

Para além da distinção conceptual, no seu trabalho teve igualmente importância uma pressuposição central, de carácter bio-fisiológico, que se refere ao funcionamento geral do sistema nervoso. Trata-se de uma função assinalada nos seres vivos em geral de afastamento das fontes de excitação que perturbem excessivamente o sistema psíquico, tornando assim viável a estabilidade interna. Esta última opera nas formas mais imediatas da sensação e do controlo-resposta aos estímulos externos segundo a resiliência do aparelho sensório-motor, mas também nas modalidades mais complexas da memória e, aqui, da referência retrospectiva aos estímulos. No limite, o sistema nervoso poderia mesmo estabelecer um estado geral de "não-excitação". Relativamente a esta tendência de equilíbrio por regulação e adaptação do sistema nervoso, no Homem, as pulsões psíquicas apresentam um valor de perturbação muito maior e mais constante que a excitação causada pelo "exterior". Esta análise diferenciadora de níveis de pressão é muito típica do modelo freudiano, que supõe a distinção entre sistema e meio e, especialmente, a constituição no sistema de modelos do meio. A análise da pulsão psíquica mostra como estamos perante um conceito que implica a auto-referência do sistema psíquico.

O sistema nervoso relaciona-se igualmente com as fontes de excitação

${ }^{2}$ Idem, "Pulsions et Destins des Pulsions" in Idem, Métapsychologie, Paris, 1968, pp. 11-43. 
externa de um modo relativamente determinado e equilibrado, bastando ter para isso presente o significado do "princípio do prazer" para o aparelho psíquico no seu conjunto. A diferença entre prazer e dor está associada a um decréscimo ou acréscimo da pressão no sistema nervoso. Se nos colocarmos na perspectiva biológica, então é possível perceber a pulsão psíquica como qualquer coisa que tem lugar no limite entre o que chamámos "psíquico" e o chamado "somático" e, então, é possível atribuir ao próprio corpo a fonte de onde jorra a energia psíquica e, graças a esta ligação ao aspecto somático, é possível ainda submeter o universo pulsional "interno" à diferença do prazer e da dor. Ora, isto significa no fundo afirmar que, na economia psíquica da pulsão, o corpo é uma referência do sistema psíquico, um feixe de efeitos da modelização do meio-ambiente interno do (e pelo) sistema psíquico.

A Psicanálise salienta o facto de o objecto da pulsão ser o que há de mais variável na pulsão. Sendo assim, compreende-se o motivo de uma definição tão larga de objecto da pulsão, quando é dito, simplesmente, que o ob-jecto é aquilo que por si ou por meio de si permite à pulsão atingir a sua finalidade, tomando por "finalidade" da pulsão a sua satisfação. Pelo facto de o ob-jecto da pulsão ser o elemento mais variável da estrutura da pulsão é que se justifica que se fale em fixação da pulsão sempre que nos deparamos com uma regra mais fixa de associação entre certos ob-jectos e certas pulsões. Por outro lado, vale ainda o princípio segundo o qual um mesmo ob-jecto pode servir à realização de mais que uma pulsão.

Igualmente variável para a pulsão é a sua fonte no corpo em determinados órgãos, de tal modo que, neste caso, a determinação científica mais exacta das fontes somáticas das pulsões não deve pertencer à Psicologia.

Há a possibilidade de identificar dois tipos mais significativos de pulsões quanto às suas fontes e que são as pulsões do eu ou de auto-conservação e as pulsões sexuais. Estes dois tipos de pulsões estão muitas vezes associadas e Freud observa que o facto de a Psicanálise se ter debatido desde cedo com as pulsões sexuais se deveu ao tipo de afecções clínicas mais usualmente estudadas, como foi o caso com as neuroses e as neuroses obsessivas. As pulsões sexuais só secundariamente se encontram associadas com a reprodução da espécie, estando primeiramente relacionadas com a finalidade de obtenção de prazer orgânico e, nesta medida, elas estão relacionadas com as pulsões do eu. Estas últimas podem, inclusivamente, servir de encaminhamento parcial às pulsões sexuais revelando determinadas vias de consumação. As pulsões sexuais conhecem quatro tipos de destinos diferentes: a transformação no seu contrário, o retorno e investimento na própria pessoa, o recalcamento e a sublimação ${ }^{3}$.

É em redor desta quádrupla destinação das pulsões que se reconstroem

\footnotetext{
${ }^{3}$ Idem, Ibid., p. 24.
} 
as diversas hipóteses relativas a uma dinâmica do aparelho psíquico.

Na dinâmica pulsional do psiquismo podem contar-se várias combinações binárias relativas a orientações possíveis das pulsões. Nos esquemas do ensaio sobre as pulsões têm especial importância aqueles mecanismos que levam às sensações de prazer e de dor, assim como os que levam à dualidade do olhar e ser visto.

No retorno e investimento na própria pessoa, o processo mediante o qual se dá a passagem da actividade na passividade é o narcisismo. As pulsões atravessadas pelos mecanismos narcísicos, relacionados com defesas, tendem a um funcionamento auto-erótico. Quando se trata do "auto-erotismo" diz-se que é um fenómeno de apagamento do objecto da pulsão em favor do órgão que é tomado como fonte da pulsão, sendo um só com esta última.

Quando se analisa a inversão do conteúdo, no caso da transformação do amor em ódio, revelam-se também as dificuldades da redução do amor a uma pulsão sexual parcial. $\mathrm{O}$ amor pertence não a um mas a três eixos de oposições binárias.

\begin{tabular}{|l|l|l|}
\hline \multicolumn{3}{|c|}{ Amor } \\
\hline AMAR/ & AMAR/ & "SENSIBILIDADE" \\
/ODIAR & /SER AMADO & $\begin{array}{l}\text { AMOROSA/ } \\
\text { /INSENSIBILIDADE }\end{array}$ \\
\hline
\end{tabular}

A situação correspondente ao narcisismo é a de um "amar-se a si mesmo". No "amar-se a si mesmo" estão referidos os pólos de actividade e de passividade que ulteriormente podem ser identificados com o "masculino" e o "feminino" o que, na linguagem dos místicos, se exprimia no "Deus esposo" e na Alma, duplamente feminina, da "mulher prometida ao seu Senhor". A diferença entre sensibilidade / insensibilidade permite evidenciar no narcisismo um tipo de investimento pulsional que toma o eu como seu destino e é possível segundo uma larga indiferença e insensibilidade em relação ao "mundo exterior". É na medida em que se gera um desinteresse ou desinvestimento em relação ao mundo exterior que o sujeito se pode descobrir simultaneamente como fonte e destino da pulsão. Assim, a noção de narcisismo e de investimento narcísico da pulsão associa-se ao diferencial interno / externo do próprio sistema psíquico e é de certo modo a prova da sua consistência ${ }^{4}$.

Tomando o narcisismo como ponto de partida Freud definiu o amor

${ }^{4}$ Leia-se: Idem, "La Théorie de la Libido et le Narcissisme" in Idem, Introduction à la Psychanalyse (trad. V. Jankélévitch) Paris, 1984, pp. 389-407. 
como a "relação do eu com as mais íntimas fontes de prazer". Para que se desenvolva esta relação de um modo adequado é necessário que o eu e as pulsões que se voltam para o eu passem pelo crivo do "princípio do prazer". Mas como o eu é o centro desta experiência, tudo o que ele conceba no mundo exterior como fonte de prazer é nele interiorizado, no mesmo sentido em que S. Ferenczi havia referido o "sentido da introjecção"5, e tudo o que nesse mesmo mundo lhe apareça como fonte de dor é expulso para fora. Trata-se de um caso especial da relação psíquica entre real $<\longrightarrow$ virtual, mas também de um modo de articular a relação entre sistema e meio e um desenvolvimento do diferencial interno / externo.

Com a apropriação narcísica das características do mundo exterior e graças à interiorização, o eu que é fonte de distinção entre "realidade" e mundo "interior", de que se havia partido, perde esse valor e transforma-se no que se chama "eu-prazer". O mundo exterior é por este mecanismo dividido naquilo que o eu aproveita e naquilo que ele rejeita, tornando-se o eu na fonte de referência de tudo. A diferença entre amor e ódio depende desta capacidade do $\mathrm{eu}$ de se tornar o centro doador de significado pulsional a todos os objectos. A possibilidade de amar reside sempre na possibilidade de interiorizar o objecto e o ódio é o efeito que começa por se situar numa zona de indiferença para progressivamente se confundir com a coisa propriamente odiada e, por fim, expulsa. Quando o objecto é positivamente denotado falamos de uma "atracção" do eu pelo objecto. Percebe-se nesta descrição do dinamismo psíquico da formação narcísica do desejo como o nexo real $\longrightarrow \longrightarrow$ virtual supõe uma certa passagem contínua de um pólo no outro, ou seja, o indivíduo representa a diferença entre uma posição virtual e o seu reflexo no real.

Com isto, Freud afirma que a relação amorosa, no seu sentido rigoroso de relação baseada na identificação, é uma relação que parte do $e u$, das "pulsões do eu" e não das "pulsões sexuais" no seu significado habitual. Mas é também neste ponto que ele dá um salto lógico no seu raciocínio quando nos afirma que a relação própria de amor do eu pelos seus objectos tem de se organizar, em última análise, sob "o primado dos órgãos genitais e ao serviço da função de reprodução"6. Esta ideia implica uma certa visão do desenvolvimento da maturação sexual, da sua teleologia.

O que chamamos o processo ou ciclo do amor é esclarecido da seguinte maneira. Na sua génese o amor estrutura-se em redor de uma identificação narcísica. Estende-se aos objectos incorporados / interiorizados pelo eu. $\mathrm{O}$ amor manifesta-se na tendência do eu para estes objectos enquanto fontes de prazer mediante o cruzamento com aquilo que o aparelho psí-

\footnotetext{
${ }^{5}$ Idem, "Pulsions et Destins des Pulsions" in Idem, Métapsychologie, op. cit., p. 37.

${ }^{6}$ Idem, Ibid., in op. cit., p. 40.
} 
quico organiza segundo o "princípio do prazer" e o diferencial emocional prazer / dor. Por esta via acaba por se ligar "intimamente" com a actividade das pulsões sexuais. Por fim, coincide com a tendência sexual na sua totalidade, uma vez "cumprida a síntese"7.

Portanto, o desenvolvimento do narcisismo e do amor narcísico acompanha a maturação das próprias pulsões sexuais. Sendo a fase genital do desenvolvimento da sexualidade a "mais bem conseguida" em termos de adaptação às finalidades da reprodução da espécie e da vida social, é natural que se lhe atribua uma importância decisiva na chamada "síntese". Disto dá conta Freud na sua teoria das fases da maturação da sexualidade.

No percurso posterior a Freud, M. Klein irá explorar os aspectos da relação amor / ódio na constituição dos objectos internos no desenvolvimento da criança tomando por elemento de análise mais decisivo a noção de introjecção e o que esta última implica relativamente a uma assimilação da realidade pelo aparelho psíquico, temas a que vamos regressar mais adiante.

$\mathrm{Na}$ construção da teoria psicanalítica sobre a estrutura do psiquismo como um "aparelho" a teoria da pulsões é axial não apenas pelo que representa da dinâmica psíquica mas também na medida em que se associa com as ideias sobre a identificação e o narcisismo, como vimos. É esta combinação que garante um modelo auto-referencial ao sistema psíquico e a autonomia sistémica do "psíquico" em relação ao "biológico", que J. Lacan vai consagrar no seu conceito de sujeito e na tese, que por si só envolve uma tópica sistémica, de que "o pensamento começa no inconsciente". A gramática do "mesmo" e da identidade, o aủ ós, serve também a meta da constituição da auto-referencialidade psíquica.

O Seminário do ano 1961-1962 de J. Lacan sobre a Identificação retoma logo de início o tema da relação entre narcisismo, auto-erotismo e identificação. A identificação é compreendida como um processo que se desenvolve na forma do pensamento, mas este último não é reduzido a um estado da consciência totalmente transparente ao sujeito. Como um processo feito de momentos de ligamento e separação, a identificação supõe nexos com dimensões imaginárias e simbólicas da articulação do sujeito em que se inclui a sua dimensão corpórea.

Refazendo o fio que levou aos temas do Seminário sobre a Ética da Psicanálise e o sentido da sequência dos seminários anteriores, as análises de J. Lacan de 1961-1962 começam com a relação entre narcisismo, auto-erotismo e identificação e vão no sentido de situar a identificação no tema lógico da identidade, à luz da discussão do princípio de identidade $(\mathrm{A}=\mathrm{A})$. $\mathrm{O}$ facto de, aqui, no enunciado mais tradicional da identidade

${ }^{7}$ Idem, Ibid., in op. cit., p. 41. 
da Filosofia clássica, o estabelecimento do idêntico estar associado ao desdobramento, dualização ou repetição do que é "idêntico" (o A em A $=\mathrm{A}$ ) constitui um ponto essencial da argumentação. A identidade para poder ser exprimida, enunciada e, depois, reconhecida, precisa de sair de si e mostrar-se como igual a si mas num outro. $\mathrm{Na}$ sua faceta mais marcante trata-se de um espaçamento do idêntico a si como condição da própria identidade, em que se recorre à repetição da letra $\mathrm{A}$ e à mediação do símbolo gráfico da igualdade. A identificação é, pois, movimento de inscrição de qualquer coisa ( $R$, real) na relação consigo (I, imagem) e com o que serve de designação da identidade (S, símbolo).

$\mathrm{O}$ reconhecimento das formações da identidade do mesmo no funcionamento psíquico é a tarefa de um conceito psicanalítico da identificação, isto é, da explicação deste desdobramento do mesmo no sujeito à semelhança da duplicação e desdobramento do A do princípio de identidade. A clarificação do funcionamento do mesmo na linguagem e no sujeito como um tornar-se outro permanecendo o mesmo é tanto mais relevante quanto mais atentos estivermos à retomada do mesmo em expressões derivadas do grego aủ ós e dos latinos ipse, ipsa, ipsum mas, aqui, sobretudo no recursivo e duplicativo metipsissimum - o si mesmo, soi même, Self - e também às consequências da reflexão subjectiva sobre a estrutura pronominal da linguagem. Este último aspecto interessa-nos especialmente na medida em que as formas pronominais estão intimamente ligadas à estrutura do aparelho de enunciação da linguagem verbal que se supõe estar regulado no ponto de partida na posição de um eu-emissor. A identificação entre um eu-emissor e um eu-pensamento, a crença na sua mesmidade, é não só uma convenção do sistema da enunciação como também uma indicação de que a alocução linguística está embebida num tecido identificatório imaginário.

O que J. Lacan recorda é que para haver explicitação, enunciação ou expressão da identidade (do sujeito) esta se tem de calcular, desenvolver, duplicar, em suma, fazer-se outra e usar os duplos como designadores do um. $\mathrm{O}$ que a teoria dos sistemas com o seu conceito de auto-referência também mostra à sua maneira é que a identidade do mesmo é uma posição recursiva no sistema da relação entre sistema e meio e supõe uma inscrição e um cálculo da diferença entre as posições reflectidas como identidade e alteridade, auto-referência e hetero-referência.

Deste modo, a identificação como processo que combina dimensões do real, do imaginário e do simbólico distingue-se da identificação de objectos fora da mente mediante as coordenadas físicas do espaço e do tempo, em que havia exclusivamente assentado o conceito da identidade referencial do positivismo lógico. $\mathrm{O}$ objecto da identificação que tenho vindo a clarificar não é o mesmo dos objectos da Física. O reconhecimento 
desta diferença tem óbvias consequências no que se chamar experiência ou "objecto empírico" da experiência assim como no que nos propusermos entender por referência, por exemplo nas teorias linguísticas da referência. A ideia de que é possível construir-se um modelo da referência com base no conceito de objecto resultante do encontro entre as coordenadas físicas da percepção vulgar e a percepção como dimensão da mente é parcial para não dizer que falseia a estrutura psíquica completa em que repousa a constituição da referência. Ela resulta apenas da descoberta do ponto de encontro entre percepção e mundo físico e é neste sentido uma teoria da percepção do mundo físico.

No que diz respeito ao sujeito da Psicanálise, o cálculo da sua identidade e do processo da sua identificação faz-se num meio que atravessa o pensamento e a linguagem e que o Seminário sobre a Identificação, recuperando Saussure, clarifica como uma "identificação de significante"8, diferenciando-a da "identificação imaginária" . Se a "identificação de significante" está baseada na sequencialidade da cadeia dos significantes, na actualização de signos na comunicação segundo nexos de significantes e significados (S / s) e na capacidade de formar sentido a partir das diferenças nessa cadeia projectando ao mesmo tempo o sujeito, já a "identificação imaginária" depende da geração de uma relação biunívoca entre um ser do mundo físico e uma imagem num domínio caracterizado por um tipo de existência virtual. Este nexo é revisitado pelo psicanalista a partir das suas teses anteriores sobre o "Estádio do Espelho como formador da Função do Eu" (1949) ${ }^{10}$. O nexo virtual que se cria entre a imagem virtual e o ser empírico da identificação do objecto físico não tem uma existência só físico-empírica ou só virtual, pois é graças a ele que a relação entre as duas dimensões se estabelece como uma autêntica dimensão empírico-virtual. Percorrer este nexo é ir de um campo ao outro, no "mesmo". O estabelecimento da identidade supõe um percurso neste corredor. Assim, a identificação num meio imaginário goza sempre do postulado da equivalência dos dois domínios e de uma passagem quase insensível do real no virtual e inversamente, como no exemplo da imagem de uma montanha num espelho, em que a condição de reconhecimento da montanha depende da relação com o seu reflexo. A identidade é fruto da relação biunívoca entre os elementos que se dão neste meio real $<\longrightarrow$

8 J. Lacan, Le Séminaire. L' Identification 1961-1962, staferla.free.fr/S9/S9\%20 L'IDENTIFICATION. pdf, p. 22.

${ }^{9}$ Idem, Ibid., p. 24.

${ }^{10}$ Idem, "Le Stade du Miroir comme formateur de la Fonction du Je - telle qu'elle nous est révélée dans l' expérience psychanalytique" in Écrits I-II, Paris, 1966, 1971, tomo I, pp. 89-97. 
virtual. No pensamento e nas representações do sujeito individuado na construção da sua identidade isto implica estar no seu ser e fora do seu ser, o que desmente a identidade e coincidência imediata do pensamento e do ser do cogito cartesiano. O posicionamento do sujeito no cume dos efeitos das suas identificações imaginárias significa que onde ele pensa ele não é e onde ele é ele não pensa ou, invertendo directamente a famosa fórmula de Descartes, eu penso, logo (não) estou.

$\mathrm{Na}$ "identificação imaginária" a distinção entre o real físico-empírico do objecto e a forma virtual da sua imagem não pode ser apagada quando referimos a identidade de ambos sendo, pelo contrário, essa mesma distinção e distância que tornam a identificação um movimento e não um estado. Com a "identificação de significante" algo de semelhante ocorre mas na suposição da estrutura completa da língua e dos valores opositivos e diferenciais dos significantes. Um significante caracteriza-se por não ter qualquer identidade e por depender, na sua definição, da serialidade e de distinções contrastivas em que uma unidade só é representativa mediante a sua diferença em relação a outras unidades. Assim, a identificação que se venha a inscrever na "cadeia de significantes" é um processo devedor da função produtiva das diferenças. Para o indivíduo, a identificação com significantes implica estar referido a uma malha construída com base na posicionalidade diferencial significante, em que nada é um valor em si. Em que, por isso, o que é aparentemente simples de um significante, ao se definir, se refere à multiplicidade contrastiva e se nega na simplicidade. Por intermédio desta malha de diferenças se pode concretizar a estrutura da referência nos níveis do real, do simbólico e do imaginário.

No centro das análises que farei a seguir do caso da paixão da Soror Mariana nas Cartas Portuguesas está o problema da relação entre o aparelho da enunciação linguística, a posição relativa de emissores e destinatários, e os mecanismos de identificação. Veremos que as formas da "identificação de significante" supõem as posições virtuais-ficcionais do emissor e destinatário das cartas e estão embebidas sempre no tecido da identificação imaginária. A questão é a de saber de que modo a verdade do sujeito em processo de identificação amorosa imaginária, pelo discurso epistolar, fica preso de nexos comunicativos que não consegue dominar e que representam um dos limites dessa identificação imaginária. Esta sua impotência em concretizar o trajecto identificatório, passando ao acto e retornando a si do outro, tem a sua razão de ser no facto de o indivíduo apaixonado estar sempre alienado, na condição de refém da resposta concreta de um outro ser humano. Esta situação de ser-refém da palavra do outro situa-o duas vezes na impossível transparência da sua identidade: na relação consigo mesmo pela consciência barrada no acesso ao mais fundo do seu desejo e na relação consigo mediante o reflexo comunicativo 
da relação com o objecto de amor em que acredita vir a encontrar-se a si mesmo.

O que tenho vindo a significar na expressão da "individuação moderna" refere-se a uma consequência que extraí das teses da Teoria dos Sistemas Sociais (Luhmann) sobre a "sociedade moderna", entendida como um resultado evolutivo da crescente autonomia dos sistemas baseados na comunicação em relação aos sistemas psíquicos ${ }^{11}$. Designa igualmente o facto de a verdade do sujeito não estar mais disponível num nível integrador como seria o da "existência humana", "situação existencial" ou equivalente. Os efeitos evolutivos da autonomia sistémica não se reconstroem, portanto, na modalidade de um si capaz de um saber da sua situação que lhe garanta a satisfação de uma transparência na forma de uma auto-compreensão da existência ou na forma de uma libertação dos constrangimentos do aparelho psíquico de um sujeito a ser resgatado da sua insuprimível fragmentaridade. Na modernidade, o sujeito é sempre semblante, desfiguração de semblante, uma posição entre semblantes ${ }^{12}$. Ele não pode suprimir o seu deslocamento relativamente a si próprio, pela divisão interna que o caracteriza, e ao outro, na comunicação que não domina. Por isso, a crítica das ilusões do sujeito, do si mesmo, deixou também de prometer a cura da sua fragmentação. Pela mobilidade, capacidade de desalojamento de formas e impossibilidade de definição substantiva, os efeitos da autonomia moderna dos sistemas psíquicos e da comunicação dão-nos a definição mais exacta da individuação na forma da não-coincidência consigo mesmo do sujeito. É também por esta caracterização, de aparência negativa, que se entende por que o sujeito moderno tem sempre a sua fonte na individuação e é uma emergência da individuação. Na medida em que perdeu a relação com a verdade no sentido de uma adesão transparente a si mesmo, ao mundo ou à "natureza" e por se apreender somente nas diferenças que o produzem na contingência, o indivíduo moderno é um feixe de acontecimentos que resultam de vários nexos entre sequências de operações e de elementos diferenciados dos sistemas psíquicos e da comunicação, como expliquei a respeito do conceito de multilinearidade em trabalhos anteriores. O efeito de cruzamentos de sequências multilineares, psíquicas e comunicativas, não corresponde a uma unidade separada da sua própria contingência, descobrindo-se nela

11 Cf. E. Balsemão Pires, A Individuação da Sociedade Moderna, Coimbra, 2011, pp. 14-18.

12 Sobre este tema e o valor das aspirações a um "discurso que não seria do semblante" remeto o leitor para as lições merecedoras de um mais longo comentário de J. Lacan, Le Séminaire. Séminaire - Livre XVIII - D’un Discours qui ne serait pas du Semblant, Paris, 2007. 
como distinta da contingência, mas é apenas um acontecimento, uma posição relativa. Isto não faz desse efeito algo menos real e é esta sua realidade, que aqui tomamos como realidade da contingência, que faz dele um in-divíduo.

Continuando na linha da descrição da sociedade moderna da Teoria dos Sistemas, em trabalhos anteriores insisti na ideia de que a individuação moderna saiu da evolução que conduziu até a um tipo de sociedade e de processamento da comunicação que não precisa de garantias subjectivas. $\mathrm{O}$ aprofundamento desta autonomia justifica a referência a relações entre sistemas psíquicos e formas da comunicação de complexidade crescente e a um duplo meio-ambiente de reflexão recíproca dos sistemas comunicativos e dos psíquicos. Mas o que se produz como resultado não é uma unidade psíquica e comunicativa. A individuação não gera nem é essa unidade.

É claro que há uma vivência interior da multilinearidade e dos seus efeitos subjectivos. Afinal, é esta vivência o que define a subjectivação da individualidade. $\mathrm{O}$ que afirmo é que essa vivência não se pode caracterizar como um saber de si na acepção do conceito de saber do sujeito, como coincidência consigo mesmo, com o mundo ou com a "natureza", ou ainda no que J. Lacan consagrou como o "sujeito suposto saber". À luz das consequências radicais da condição moderna o saber de si do sujeito não adere à vivência de si e ao ser. A análise de uma tal não-adesão no sujeito da consciência, do ser e da vivência representa para nós o desafio do confronto com Hegel e com a sua "ciência da experiência da cons-ciência". Dizendo-o de outra forma: para designar o conteúdo da vivência subjectiva do in-divíduo moderno é preciso uma ciência das condições e dos efeitos da multilinearidade. Eis a consequência que se produz quando a condição moderna barra por duas vezes ao sujeito o acesso interior à coincidência consigo mesmo e ao seu ser ou à sua "natureza", uma vez na forma psíquica e outra na forma comunicativa.

Mesmo quando as Filosofias da Existência e as correntes da Hermenêutica julgaram ter ultrapassado a estreiteza evidente do que se chamou "Teoria do Conhecimento" ao partirem da ek-sistência e abertura ao mundo do Homem (não obstante as debilidades que Heidegger identificou neste conceito de "Homem") continuavam a situar-se no terreno de um sujeito capaz de posicionar a partir de si, nomeadamente como "projecto", a sua verdade de "subjectum", de suporte, estrutura subjacente, "substância". A abertura existencial ao mundo, a auto-compreensão do seu próprio ser continuam situados na rota de uma iniciativa do próprio, de uma via que parte da dominação da abertura, de uma transparência a si ou da sua promessa final como produto de uma história da auto-apropriação. O tema do amor posiciona-se aqui na via de uma auto-gnose, embora difícil e 
árdua, e sem dúvida caracterizada com o termo de finitude, mas é sempre um retorno a si do outro, como co-prehensio. Precisamente, o que aqui, nestas concepções, não foi possível perceber do amor foi o facto de ele ser sempre sem retorno, identificação com outrem mas sempre já entregue ao poder real da comunicação, que se furta a qualquer controlo psíquico, como veremos a propósito do funesto mas não menos verdadeiro, humanamente verdadeiro, destino da Soror Mariana, e também amor alienado nas projecções identificatórias do outro sobre si mesmo.

Na evolução da percepção moderna da autonomia da consciência e da comunicação e da multilinearidade que dela decorre, que marca a individuação como efeito multilinear, teve um papel sintomático a Psicanálise, a compreensão psicanalítica da pulsão mas mais especificamente, no que nos importa de seguida, a inclusão por Freud do amor na sua teoria das pulsões e da identificação. Aqui vemos ilustrada esta ideia de um sujeito barrado no aceso à coincidência consigo mesmo, na sua dimensão psíquica, na medida em que o sujeito, na tentativa de se apropriar de si, não pode deixar de estar submetido ao poder de identificações imaginárias que ele não pode integrar num saber consciente integral. Veremos de seguida mediante o nosso "caso" como o tema da identificação na sua dupla inscrição imaginária e simbólica, na forma psíquica e na comunicativa, constitui um ponto de passagem obrigatório da nossa proposta de uma teoria da individuação.

A concepção psicanalítica das pulsões e do amor como pulsão, em particular, é uma das revelações teóricas da autonomia moderna da comunicação e da consciência. Prolongar a análise do sujeito barrado nas formas da comunicação, para além da sua barra psíquica, que a Psicanálise identificou no seu conceito de aparelho psíquico, é tomá-lo como efeito da in-dividuação gerada em formas psíquicas $e$ em formas sociais (comunicativas). Quer dizer, trata-se aqui dos efeitos de uma dupla barra, psíquica e comunicativa, com a consequente rotação dos quatro eixos da individuação nos dois sistemas - psíquico e comunicativo. Assim preencho o que comecei por identificar em trabalhos anteriores na forma radial simples do modelo dos quatro eixos. A necessidade deste complemento do modelo inicial reflecte também os progressos na formulação do conceito de um duplo meio-ambiente no trabalho anterior sobre a consciência e a comunicação em W. James e C. S. Peirce ${ }^{13}$.

Introduzo agora um modelo do esquema dos quatro eixos adaptado à

${ }^{13}$ E. Balsemão Pires, "Communication and Consciousness in the Pragmatist Critique of Representation: W. James and C. S. Peirce" in European Journal of Pragmatism and American Philosophy vol. 3, n. 1, 2011, pp. 6-29. 
rotação recíproca dos quatro eixos para os dois sistemas acoplados pólo a pólo. Neste modelo, o índice $\mathrm{ps}$ representa o sistema psíquico e co a comunicação. Em vez de as relações pressupostas estarem subordinadas a uma única forma de observação e de re-entrada, vamos relacionar cada um dos pólos de um sistema com o seu simétrico no outro sistema (virtualidade (v) $\longrightarrow \longrightarrow$ realidade (r), actualidade (a) $<\longrightarrow$ potencialidade (p), sucessão ( su) $\longrightarrow$ simultaneidade (si), simplicidade (s) $\longrightarrow$ multiplicidade $(\mathrm{m})$ ). Conseguimos assim um modelo formal completo do acoplamento sistémico ( $\mathrm{ps}_{\mathrm{co}}$ ) e a estrutura da individuação psíquico-comunicativa, que se presta às mais diversas ilustrações empíricas.

II. As Cartas Portuguesas e a "pessoa" Mariana Alcoforado

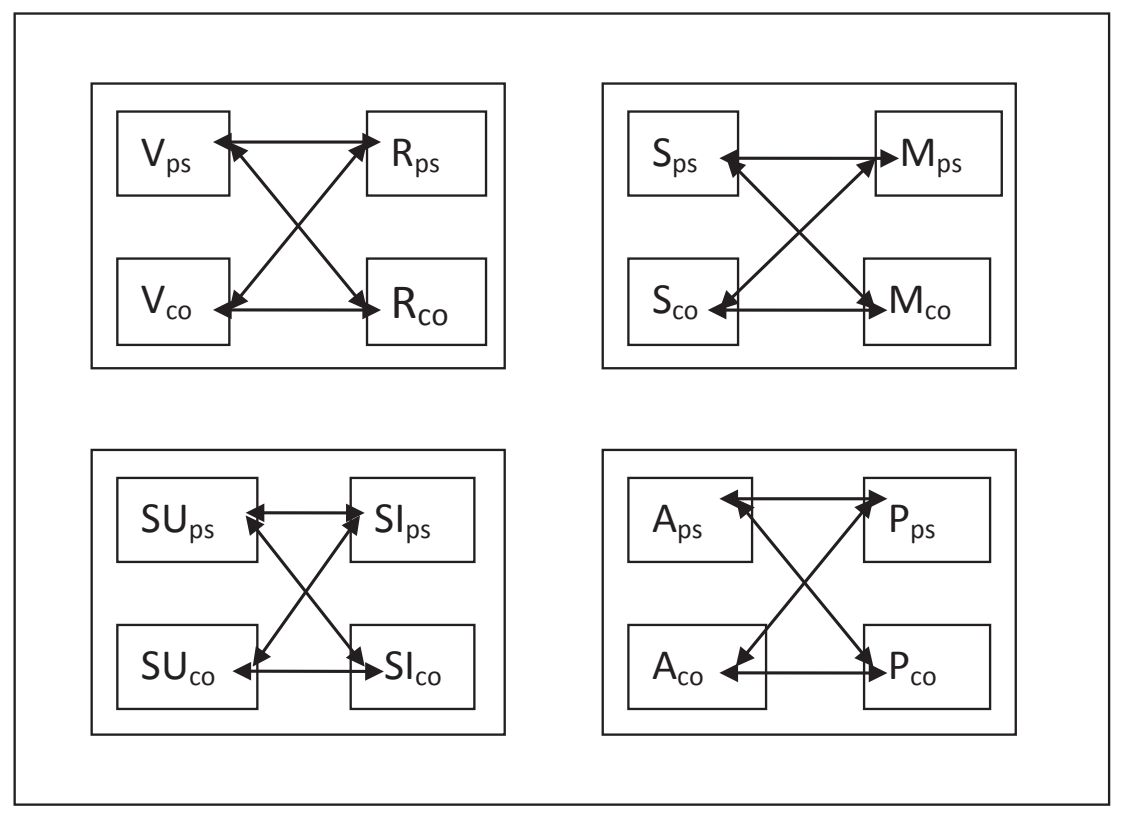

Vou centrar-me agora na análise de alguns aspectos da relação entre expressão do sistema psiquico e comunicação nas Cartas Portuguesas, tomando-as como uma ilustração ficcional do código moderno do "amor como paixão" e do modelo dos quatro eixos da individuação do sujeito.

Tentarei mostrar, também, como essa relação central tem os seus efeitos na individuação do(a)s autores de "cartas de amor" e como desta relação depende a ficcionalidade da comunicação epistolar. Esta vai ser 
analisada como um tipo especial de identificação no corredor real $\longrightarrow \longrightarrow$ virtual.

Nas análises vou referir-me às rotinas comunicativas geradas em consequência do mecanismo psíquico conhecido na História da Psicanálise como "identificação projectiva" e mostrar como a comunicação literária epistolar das Cartas Portuguesas põe em evidência a autonomia da comunicação frente às projecções imaginárias do sistema psíquico e, com isso, gera a situação paradoxal que motiva a nossa admiração estética por este texto e a posição da sua autora implícita perante a paixão, na cruel flutuação entre o erotismo do coração e o erotismo místico.

A individuação da autora implícita das Cartas Portuguesas implica dois desdobramentos associados a duas divisões: o desdobramento da figura psíquico-comunicativa da autora numa face psíquica e numa face comunicativa; o desdobramento da autora entre o emissor empírico e o emissor ficcional. Por outro lado, as duas divisões são as que separam por um lado as pressuposições relativas a um autor-homem das referentes a um autor-mulher e, no autor-mulher, a mulher como objecto erótico e sujeito de sedução, distinta da mulher casta e reclusa (a freira).

Veremos como a situação paradoxal em que se envolve o autor implícito do texto supõe e se deve em parte às possibilidades de representação simbólica do papel da mulher na época do "Ancien Régime" entre irmã, esposa e freira, e como um ou outro tipo de reclusão está sempre associada a essas possibilidades.

Não me ocupo do tema histórico da atribuição das "Cartas Portuguesas" a autores empíricos definidos. Os historiadores e biógrafos possuem aqui um campo de investigação que parece muito longe de estar esgotado. A minha ideia foi rever nas Cartas um caso excepcional de ilustração da estrutura psíquica e comunicativa da relação amorosa do "amor como paixão", a divisão e consequente individuação do sujeito-autor através da autonomia e acoplamento dos elementos psíquicos e dos elementos comunicativos do sentido na forma da ficção da comunicação íntima.

Usarei sempre a referência a SMA, "Soror Mariana Alcoforado", como uma assinatura do autor implícito do texto e não como referência empírica directa a um autor empírico com o mesmo nome. SMA será, doravante, ao longo deste trabalho, a "persona" do texto de As Cartas Portuguesas 14 .

Para designar o autor implícito e a estrutura comunicativa epistolar não prescindirei desta figura da freira de Beja. Exigência esta que não deixa de nos levar a um ponto da teoria em que voltarei a insistir, sobretudo em

${ }^{14}$ A edição que segui foi a publicada em francês pelo editor C. Barbin, Lettres Portugaises traduites en François, Troisième Édition, à Paris, chez Claude Barbin, 1672. 
virtude deste exemplo da Soror Mariana. Refiro-me à dificuldade em isolar o emissor das cartas da presunção da existência de uma irmã Mariana a viver em Beja, no século XVII, em pleno padecimento de amor. Entre o autor implícito das cartas e a SMA histórico-real se gerou um corredor virtual $\longrightarrow \longrightarrow$ real em que as identificações ocorrem em ambas as direcções: quando lemos as cartas imaginamos a irmã e quando conhecemos a história pessoal de Mariana Alcoforado pensamos nas cartas. A causa deste rumor sobre uma Mariana-autora-das-Cartas está no ciclo comunicativo que tem por tema "Soror Mariana Alcoforado". Procurá-la na unidade psíco-física da freira com esse nome é vão.

Sobre a figura real de uma freira de nome Mariana as informações do critico e biógrafo Luciano Cordeiro são interessantes, na medida em que nos transportam até ao que podia ser o referente não-ficcional SMA e a "cena de família" em que, a ser ela a vítima-escritora dos males de amor, se teria de inscrever. E uma cena forjada com elementos do imaginário sobre o género, o status social familiar e o património, em que não falta a relação simbólica estruturante irmão - irmã ${ }^{15}$.

Das suas pesquisas concluiu L. Cordeiro que Mariana havia nascido em 1660 e fora baptizada em 3 de Setembro. A data referida no obituário do Convento estaria, pois, errada. Mariana foi filha do proprietário Francisco da Cunha Alcoforado e de Leonor Mendes. O pai é incluído na linhagem dos Alcoforado e ao que parece descendia do fundador do apelido, Pedro Martins Alcoforado, no século XII, com misturas posteriores com Cunhas e Coutinhos. Embora inserido em linhagens da nobreza as suas condições económicas não seriam as de um homem abastado e a sua ida para o Alentejo revela mesmo a história de uma posição subalterna.

O comentador e historiador das Cartas Portuguesas faz vastas considerações sobre a genealogia dos Alcoforado, mas de todas elas talvez a suposição mais importante para reconstruir a "cena de família" imaginária é a de que Mariana teria sido feita professa no convento de Beja para tornar mais fácil a perpetuação do nome e do morgadio nos irmãos, no irmão mais velho, ao abdicar da sua parte na herança. Segundo esta suposição Mariana estaria desde os 3 anos prometida a uma vida de freira, em virtude da sua condição de irmã do herdeiro e filha de um pai de posses pouco mais que sofríveis para a condição, embora tivesse de esperar pelos 12 para se determinar legalmente à vida de reclusa. Para além de Mariana havia duas outras irmãs do mesmo casal, Maria Peregrina e Ana Maria. O biógrafo refere ainda mais uma irmã, Catharina, igualmente destinada a uma vida de reclusão conventual, mas possivelmente falecida ainda jovem. Trata-se de uma filha de outra relação do pai de Mariana, de

15 L. Cordeiro, Soror Mariana, a Freira Portuguesa, 2ª Edição, Lisboa, 1890. 
que nasceu também Maria da Conceição. Coincide com a mesma data da entrada de Mariana no convento a morte da mãe, o que poderá ter reforçado o motivo da entrada para o Convento pela impossibilidade de o pai se dedicar à educação das filhas. Das três irmãs só uma casou, Ana Maria. Maria Peregrina ingressou também no convento. O nome conventual da irmã mais nova de Mariana foi Dona Peregrina Maria Alcoforada. Mariana educou-a. Em 1690, D. Peregrina já era escrivã do Convento. Em 1696 terá deixado estas funções. Entre as tarefas que lhes estavam destinadas como escrivã encontrava-se o registo dos óbitos das freiras. De 1730 a 1732 Dona Peregrina Maria aparece como abadessa do Convento.

O hipotético destinatário das cartas, Noël Bouton, Marquis de Chamilly, teria ficado a dever prestígio e mesmo a designação de "cavaleiro" ao Rei português que assim o nomeou enquanto esteve em campanha contra os espanhóis durante a Guerra da Restauração, ao serviço de Portugal. Na sua companhia teria combatido Baltazar Vaz Alcoforado, irmão de Mariana, e eventual responsável, voluntário ou involuntário, do conhecimento mútuo dos dois futuros amantes.

\section{Acção e Vivência na estrutura da paixão amorosa}

Joe Bray, num estudo sobre a novela epistolar em que refere várias vezes as "Cartas Portuguesas", sublinhou um aspecto que interessa reter: a relação entre o interesse pela novela epistolar no séc. XVII e a atenção da época às formas de representação da consciência ${ }^{16}$. $O$ género da comunicação literária epistolar seria particularmente apto para revelar a "corrente de consciência" dos autores implícitos de cartas, num fluxo "livre". Alegadamente, os autores de cartas deixariam correr o pensamento como se não tivessem "censura" exterior ou, então, como se lidassem com ela no próprio processo de escrita, de diversos modos. Na relação do sujeito consigo mesmo a novela epistolar torna-se um meio expressivo da consciência e dos "estados de alma", assemelhando-se, nisto, à comunicação do diário ou da confissão. Tudo aqui parece decorrer de uma relação directa expressiva com os estados íntimos no seu fluxo intocado.

A novela epistolar é um meio de comunicação literária que exprime a "corrente de consciência" como se o autor de cartas aderisse sem mediações ao seu fluxo de consciência. Mas, em cartas, a verdade psíquica do sujeito, ou a sua autenticidade enquanto sujeito de pensamentos, é sempre

16 J. Bray, The Epistolary Novel: Representation of Consciousness, London, New York, 2003. 
revelada no limiar entre consciência e comunicação graças à mediação do aparelho linguístico da enunciação discursiva. Este aspecto pode tornar-se central no caso das "cartas de amor", em que os autores não só revelam a sua paixão como sendo a sua própria verdade, o que directamente "vai na alma", mas se submetem ainda à prova da resposta do interlocutor (ou da sua ausência). A troca epistolar e sobretudo a troca de cartas amorosas expõe um meio de descoberta da consciência mas, mais do que isso, revela um meio muito apropriado à evidenciação dos limites recíprocos da consciência e da comunicação, na medida em que reúne as características da ficcionalidade literária e a comunicação com o ausente. A estrutura da enunciação e a inclusão da diferença entre emissor e destinatário no sentido do conteúdo escrito, como uma diferença real da mensagem, parece que revela imediatamente a associação de ideias dos autores, mas na realidade remete o valor dessa revelação para o campo da resposta do destinatário que igualmente se institui na estrutura.

É por isto que na sua relação com a semântica do "amor como paixão" o meio da comunicação epistolar torna transparentes as características da relação assimétrica da "paixão" moderna, em mais do que um aspecto.

A história da formação de Liebe als Passion (1982) de N. Luhmann leva-nos até 1969 data em que o autor leccionou um Seminário na Universidade de Bielefeld sobre o tema do amor, cujas notas preparatórias levavam já por título precisamente "Liebe als Passion", editadas por A. Kieserling em 2008 como Liebe. Eine Übung ${ }^{17}$.

Nos finais da década de 1960 o sociólogo estava a desenvolver as suas investigações sobre os "meios de comunicação generalizados do ponto de vista simbólico", continuando um tópico da Sociologia de T. Parsons, e havia concluído os estudos que o haviam levado à Sociologia do Direito, entre outros textos deste período, onde estava articulada uma teoria das expectativas, um pensamento da acção para além da Psicologia do Comportamento e da Motivação individuais assim como uma concepção da institucionalização.

Algumas das questões presentes na Sociologia do Direito são retomadas no seminário de 1969 e o tema-moldura da institucionalização é invocado. Aliás, o tema central é mostrar como o "amor-paixão" é uma orientação discursiva da sociedade moderna que historicamente surge para institucionalizar o Amor como "meio de comunicação generalizado do ponto de vista simbólico" ao lado de outros como o Dinheiro, o Poder, a Verdade ou a $A_{r t e}{ }^{18}$. O tema do Amor não se concebe, portanto, fora

${ }^{17}$ N. Luhmann, Liebe. Eine Übung, Frankfurt / M., 2008.

18 Os desenvolvimentos posteriores da teoria dos meios simbólicos encontra-se em 1975 e na obra de súmula de 1997, em que se oferece a sua síntese final: Idem, "Einführende Bemerkungen zu einer Theorie symbolisch generalisierte Kommunikationsmedien" in 
da Teoria da Sociedade e é tomado como uma ilustração da autonomia funcional e da complexidade resultante desta autonomia na sociedade moderna funcionalmente diferenciada.

Na Teoria da Sociedade de 1984 (Soziale Systeme) mas já na versão do seminário de 1969 de Liebe als Passion a diferenciação dos "meios de comunicação generalizados do ponto de vista simbólico" distingue-se da diferenciação de sistemas parciais da sociedade moderna como a Economia, o Direito, a Política, a Arte, a Religião ou os "Mass-Media", mas ambas as formas de diferenciação mantêm não só nexos entre si, e uma interdependência geral, como ainda são formas da mesma diferenciação funcional.

Os "meios de comunicação generalizados do ponto de vista simbólico" têm como principal característica distintiva relativamente a outras modalidades de diferenciação funcional o facto de estarem baseados na linguagem e articularem mediante significação linguística o que não possui à partida esse tipo de estruturação. No entanto, os "meios de comunicação simbólicos" produzem efeitos sociais que vão mais longe que a transmissão de mensagens ou a estabilização de expectativas mútuas mediante a partilha de significados comuns. Logo no início do seminário de 1969 N. Luhmann sustentava que os "meios de comunicação simbólicos" ligam "mecanismos de selecção" e "mecanismos de motivação". Pode imaginar-se a motivação de agentes por meio de selecções de sentido e suas divisões, que podem ser aceites ou recusadas na interacção pelos agentes. Alguém se pode (ou não) sentir motivado a amar ou a exercer poder em diferentes momentos da sua vida. Mas estas suas motivações estão socialmente associadas aos "meios simbólicos" correspondentes do Amor e do Poder que já se encontram presentes na sociedade e dependem de uma evolução social que estabilizou a sua referência, a sua relativa autonomia e a semântica correspondente.

À luz de uma divisão genérica os "meios de comunicação" podem distinguir-se consoante o sentido comunicado se refere predominantemente à vivência (Erleben) ou à acção dos agentes implicados. Esta distinção reaparece no livro de 1982 e tem a maior importância para o objectivo do estudo das Cartas Portuguesas.

A constituição do Amor, do "amour passion" em especial, como um "meio de comunicação generalizado do ponto de vista simbólico" depende de um conjunto de factores semânticos e estruturais na sociedade moderna relacionados com o que em 1969 N. Luhmann continuava a situar no terreno da "institucionalização". Na investigação do Amor como meio sim-

Idem, Soziologische Aufklärung 2, Opladen, 1975, reed. 1982, pp. 170-192; Idem, Die Gesellschaft der Gesellschaft 1, kap. 2, IX-XII, Frankfurt / M., 1997, pp. 316-396. 
bólico é necessário em primeiro lugar clarificar a relação entre a função e o código da função. A função diz respeito à prestação social que resulta da mobilização da referência ao Amor na sociedade moderna, o que daí decorre para as interacções e para a Sociedade no seu conjunto. O código representa o conteúdo semântico da função, a sua identidade relativa frente a outros conteúdos-códigos, o tecido semântico de que emerge e as oposições em que assenta. Descrever o Amor como "meio simbólico" é explicar como a sociedade moderna assegura mediante este código determinadas funções comunicativas que não assegura com a referência a códigos de outros "meios" ou deixaria de assegurar caso o código desaparecesse. As selecções de possibilidades de acções que ocorrem mediante a referência ao Amor não são as mesmas que emergem com a referência ao Dinheiro, ao Poder, à Arte ou à Verdade. Isto quer dizer que não só não fazemos as mesmas coisas quando nos situamos em cada um destes meios como as possibilidades das nossas acções e vivências são forçosamente distintas no que se diz respeito ao seu significado social e directamente para com outrem nas interacções, quando mudamos de "meio simbólico" de referência.

Os "meios de comunicação generalizados do ponto de vista simbólico" asseguram à diferenciação funcional da sociedade moderna um molde adequado ao processamento de acções, vivências e motivações de agentes segundo códigos institucionalizados de relações sociais. Amor e Dinheiro, por exemplo, são meios simbólicos na medida em que por meio da sua referência geral se asseguram possibilidades de vivências ou de acções que estão já formadas no seu poder selector particular. É a evolução da sociedade que desenvolve condições para que as relações que se tornam possíveis com base no Amor prossigam com independência frente ao Dinheiro ou ao Poder, por exemplo. Sabemos como a autonomia relativa destes três meios teve a sua importância na codificação do casamento moderno, por exemplo. É também dessa evolução que se pode esperar (ou não) uma abstracção do que define Amor frente ao que caracteriza as relações sociais como tais. A evolução da diferenciação de sistemas parciais na sociedade moderna ao atribuir a funções sociais especializadas em sistemas a faculdade de dar respostas às prestações exigíveis à família em formas antigas da organização social acabou por condicionar o aparecimento da forma familiar moderna centrada no par conjugal de dois indivíduos enamorados. O Amor como "meio de comunicação generalizado do ponto de vista simbólico" assegura à família moderna um meio de selecção muito adequado das acções, vivências e motivações dos seus agentes. A evolução da família moderna e do tipo de casamento moderno no sentido da intimidade manifesta uma influência clara do que N. Luhmann designou por "Mitologia do Amor" na modelização dos motivos dos agentes que se vão constituir como membros de um núcleo de 
vida íntima institucionalizada ${ }^{19}$.

Na narrativa da evolução do Amor como "meio de comunicação simbólico" o seminário de 1969 traçava uma linha que ia desde a forma indistinta do amor-amizade da literatura antiga, confundida com a solidariedade ente iguais exigida para a constituição de uma Pólis, até à diferenciação moderna ${ }^{20}$.

Uma das notas distintivas dos "meios de comunicação simbólicos" e do Amor em especial reside no facto de o seu código se poder retomar do ponto de vista reflexivo. Assim, o amor não define apenas o sentimento de alguém numa relação de objecto tido como causa desse sentimento interno, "x ama $y$ ", mas alguém pode pretender amar o amor ou estar apaixonado pela paixão. Nesta circularidade o código retoma-se e reforça-se para novas comunicações. Do ponto de vista da evolução semântica, N. Luhmann considerou que a reflexibilidade do amor só está consolidada no século XVIII e dá como exemplo Jean Paul - o profeta do "sentimento do sentimento" ou do "amor do amor" (Liebe um Liebe) ${ }^{21}$. Algo de semelhante pode entrever-se já nas Cartas Portuguesas na modalidade da paixão que é considerada preferível ao seu objecto.

Ao mostrar como a comunicação íntima não pode desenvolver-se sem uma forte referência aos seus suportes psíquicos, o seminário de 1969 anunciava os desenvolvimentos sobre a interpenetração do capítulo final de Liebe als Passion de 1982. Além disso, no texto do seminário, quando remetia para os estudos do sociólogo americano W. J. Goode, de que cita a frase sintomática "Love is the most projective of emotions, as sex is the most projective of drives" 22 , N. Luhmann mostrava estar consciente da presença de mecanismos projectivos no amor e na sexualidade que só podem ser descritos e articulados na teoria social no quadro da interpenetração sistémica. Este aspecto vai ao encontro do objecto do presente trabalho sobre a identificação projectiva nas Cartas.

Em Liebe als Passion, N. Luhmann ${ }^{23}$ descreveu a estrutura e os meca-

${ }^{19}$ Idem, Liebe. Eine Übung, op. cit., pp. 32-33.

${ }^{20}$ A tradição que N. Luhmann tem presente é aquela que parte da proximidade entre philia - amicitia, que continua na "solidariedade" dos modernos, a que se deve associar o par koinonia - societas civilis. Esta forma universal, sincrética, da "amizade" acompanha a forma da diferenciação social das sociedades estratificadas concebidas segundo o modelo da "Casa". Cf. Idem, Ibid., p. 28-29.

${ }^{21}$ Idem, Ibid., p. 40.

22 Idem, Ibid., p. 88 nota 53.

${ }^{23}$ Idem, Liebe als Passion - Zur Codierung von Intimität, Frankfurt / M. 1994. Ver 
nismos associados à interacção amorosa com o sentido de clarificar de que modo o "amor", como um meio simbólico de comunicação da sociedade moderna, diferenciada do ponto de vista funcional, é responsável por um tipo bem determinado de "interpenetração" entre sistemas psíquicos e comunicação nos sistemas íntimos de tipo familiar, mas igualmente na generalização de representações sobre "relações amorosas" através de variadas pressuposições semânticas do meio simbólico, por exemplo na forma da comunicação literária que faz circular o "mito do amor".

O sociólogo desenvolve a formação moderna do tema da paixão amorosa no quadro da "evolução sócio-cultural" com referência ao amor como meio simbólico de comunicação, entre outros, mas especialmente no contexto da emergência e transformação da semântica da individualidade moderna. Esta última articula-se com os temas da paixão e dos "direitos do homem" 24 . Inclui também o tema da "construção das carreiras", o da formação e crise da autenticidade e o da transformação da moral, mas a exploração da semântica da paixão e o tema dos "direitos do Homem" merece uma atenção dedicada.

Partindo desta moldura geral da semântica da individualidade moderna é então possível descrever de que modo se organiza a forma da interacção social que tem por referência simbólica central o "amor como paixão" e o molde da individuação dos protagonistas da paixão amorosa. Aqui, tem lugar uma combinação de formas da organização psíquica da consciência, de antecipações e pressuposições comunicativas sobre o género e sobre o corpo orgânico sexuado que formam as bases das expectativas na interacção voltadas para a comunicação amorosa. O corpo orgânico sexuado representa o equivalente a um "mecanismo simbiótico" 25 do sistema psíquico, pois não deixa de o acompanhar como um referente objectivo dos sentimentos internos na comunicação. Em virtude da sua estabilidade e re-envio estrutural de elementos psíquicos, comunicativos e orgânicos, esta combinação de formas constitui um "acoplamento estrutural" na comunicação sexual, amorosa e na comunicação familiar, em especial. Os eventos que podem ser descritos como comunicação amorosa ou "paixão" combinam estes três domínios e supõem uma forma de observação relacionada com todos eles na forma final da interacção. $\mathrm{O}$ "sistema" resultante deste acoplamento reflecte uma estrutura compósita

ainda a respeito das "Cartas Portuguesas" Idem, Die Kunst der Gesellschaft, Frankfurt / M., 1997, p. 414 nota 47.

${ }^{24}$ Idem, Grundrechte als Institution. Ein Beitrag zur politischen Soziologie, Berlin, $1999^{4}$, pp. 53-83.

25 Sobre o conceito de "mecanismo simbiótico" veja-se Idem, Soziologische Aufklärung 3, Wiesbaden, 20095, pp. 262-280. 
(comunicativa-psíquica-sexual) que é a responsável pelo processamento de sentido que se refere a "pessoas" ou a indivíduos como a autênticos "agregados auto-referenciais" destes três tipos de elementos.

De acordo com N. Luhmann uma das características do código do amor romântico que vai garantir a reprodução do sistema da intimidade da sociedade funcionalmente diferenciada, ou a família no seu sentido plenamente moderno, reside na grande sensibilidade para a observação e descrição dos sintomas da paixão no comportamento dos participantes na interacção e na comunicação amorosas e desde logo no casamento $^{26}$.

Mas tanto a interacção como a comunicação no meio simbólico do "amor como paixão" se referem a uma relação assimétrica dada, como vimos atrás, na própria forma desse meio que remete para a acção e para a vivência. Esta estrutura de relações distribui acção e iniciativa num dos lados da relação e passividade e espera no outro lado. N. Luhmann designou um dos pólos por "Ego" e o outro por "Alter", à luz de uma classificação corrente. A relação amorosa no meio simbólico do "amor como paixão" implica, portanto: Ego-acção; Alter-vivência ${ }^{27}$.

$\mathrm{O}$ que de um lado aparece como iniciativa, do outro lado apresenta-se como elemento da corrente da consciência, como vivência: Ego-amante; Alter-amada(o). Partindo do esquema simplificado teremos a seguinte equivalência.

Acção: Ego-amante

\section{Vivência: Alter-amada(o)}

Esta equação que se articula no quadrado de possibilidades do Amor do capítulo 2 de Liebe als Passion motiva mais que um comentário. Lembremos apenas que segundo este modelo do amor como meio simbólico estamos perante uma relação quaternária que, antes mesmo de fazer intervir a comunicação, combina a base psíquico-orgânica (sexual) da relação amorosa segundo as duas grandes vertentes do aparelho psíquico, a acção e a vivência (representação), e duas personificações do agente e do paciente. Para compreender o amor como acção temos de o conceber no lado da causa, do instigador ou do sedutor; para o apreender como representação psíquica, como estado mental ou vivência num sentido abrangente temos de partir do pólo patológico da relação. Daqui se infere que a consciência do estado amoroso supõe afecção e retenção psíquica da afecção ao longo da orientação das vivências da consciência

${ }^{26}$ Cf. E. Balsemão Pires, A Individuação da Sociedade Moderna, op. cit., primeira secção, pp. 74-75.

${ }^{27}$ N. Luhmann, Liebe als Passion, op. cit., pp. 26-27, nota 9. 
e só na relação circular consequente se pode referir neste pólo alguma acção ou iniciativa.

Na medida em que o meio simbólico do "amor como paixão" na distribuição assimétrica dos seus dois pólos se adequa ainda à distribuição dos papéis sociais dos géneros se compreende por que a mulher se vem situar habitualmente, segundo as construções sociais de género ligadas a expectativas, no lugar patológico, no pólo da vivência, das representações da afecção, em oposição ao lugar masculino da iniciativa e da acção. A comunicação gera aqui um condicionamento geral das posições sexuadas dos actores e a sua distribuição nos dois domínios reservados para o enquadramento da sua experiência psíquica, segundo a acção e a vivência.

Contrariando a ideia de que o amor traz felicidade, no seu ensaio sobre o Amor Ortega y Gasset mostrava-se convencido que o amor feminino seria proporcional em força e intensidade à angústia que o amante conseguisse despertar na amada e dá como prova as Cartas Portuguesas ${ }^{28}$. As passagens citadas das Cartas referem-se ao sofrimento de amor ou mais propriamente ao sentimento aí expresso segundo o qual é preferível sofrer do mal de ausência do que não se conhecer de todo a paixão. A assimetria da relação passional é não só admitida como ainda desdobrada. De facto, para além da relação entre o amante e a amada Ortega refere o carácter assimétrico da relação entre a formação interior do desejo e a posição externa do objecto. Quer dizer que o "amor-paixão" não autoriza uma equivalência entre amante e amada ou entre objecto externo e objecto interno do desejo. Estes últimos não são dois pólos invertíveis.

Para o meu objectivo o interessante na tétrade de N. Luhmann reside no facto de, a partir dela, ser possível reconstruir não apenas o modelo psicológico de base do "amor como paixão" mas ainda o mecanismo psíquico que na História da Psicanálise se designou por "identificação projectiva".

As Cartas Portuguesas e o seu autor implícito, a freira portuguesa, a que chamo SMA, são ilustrações da combinação da elaboração psíquica do sentido da paixão e do seu desenvolvimento comunicativo e literário. São exemplo, portanto, de um acoplamento dos dois sistemas.

Elas dão várias provas, além disso, do enlaçamento dos eixos do modelo da individuação atrás ilustrado nas duas faces psíquica e comunicativa.

\section{A Identificação Projectiva e a estrutura do "Amor como Paixão"}

Ao longo deste trabalho o tratamento do mecanismo da identificação projectiva não se relaciona com as questões teóricas relativas à psicose ou,

${ }^{28}$ J. Ortega y Gasset, On Love: Aspects of a single Theme, (trad.), New York, 1957, p. 13. 
em geral, com as aplicações psicopatológicas. É-nos necessário contudo perceber a posição inicial da teoria da identificação projectiva no seu cenário psicopatológico na obra de alguns psicanalistas.

Nas suas observações teóricas a partir da experiência clínica, M. Klein reconheceu que o isolamento do mecanismo da "identificação projectiva" ocorreu muito antes da Psicanálise. Ela referia-se especialmente ao conceito de "empatia".

As suas observações estão correctas se as referirmos ao par "empatia-simpatia". De facto, podemos seguir a carreira semântica da "simpatia" no séc. XVIII na sua feição filosófica, com a obra germinal de Shaftesbury e na sua influência no chamado "Iluminismo Escocês" com aplicações no domínio moral e na compreensão da acção social, na obra de A. Smith sobre a Teoria dos Sentimentos Morais, mas seguramente também na Literatura.

Continuando a obra de Freud sobre o narcisismo e o amor, os dois estudos fundamentais de M. Klein sobre a "identificação projectiva" (1946, $1955)^{29}$ revelaram um importante mecanismo psíquico imaginário, parcialmente inconsciente, que emerge nos primeiros meses da vida do infans e que pode persistir na idade adulta e levar a certos tipos de doença mental, especialmente os comportamentos esquizóides. É sabido que paralelamente às reflexões sobre identificação projectiva a psicanalista desenvolvia a sua concepção sobre as duas posições psíquicas básicas do desenvolvimento infantil: esquizo-paranóide e maníaco-depressiva.

A primeira posição está relacionada com as fixações infantis no seio materno de acordo com movimentos projectivos e introjectivos da mente para o exterior ou inversamente dos objectos para o corpo-próprio e daqui para a mente.

A análise de M. Klein não teve em conta qualquer mediação linguística nas duas posições e nos processos intro- e pro-jectivos de identificação, o que a distingue da descrição lacaniana da "identificação de significante" que J. Lacan articulou depois da comunicação de Zürich de 1949. Trata--se, portanto, à luz da distinção de J. Lacan, da "identificação imaginária" e não da "identificação de significante". O modelo de M. Klein também não se focou em outros processos semiósicos para-linguísticos. Ela esteve basicamente orientada para as estruturas inconscientes imaginárias e atenta aos reflexos da infra-estrutura inconsciente do imaginário na interacção.

${ }^{29}$ Refiro-me a "Notas sobre alguns mecanismos esquizóides" (1946) e "Sobre a Identificação" (1955). Ambos os artigos foram editados em M. Klein, Envy and Gratitude and Other Works 1946-1963, The Melanie Klein Trust, London, 1975 (trad. port., M. Klein "Notas sobre alguns mecanismos esquizóides" e "Sobre a Identificação" in Idem, Inveja e Gratidão e Outros Trabalhos 1946-1963, Rio de Janeiro, 1985, pp. 17-43 e pp. 169-204). 
Contudo, a comunicação e a interacção são consideradas como extensões da projecção imaginária do ego e das suas estratégias de identificação imaginária. Isto é especialmente importante se relacionarmos os mecanismos de defesa na identificação projectiva com a ilusão de controlo sobre acções e pessoas na fantasia. A impressão de „viver através de outra pessoa" como noção de uma influência contínua da associação interna de impressões e ideias no comportamento alheio é frequentemente referida na literatura clínica a respeito de auto-observações e auto-descrições de pacientes em casos de delírio de controlo, como acontecia no caso das notas biográficas do famoso Presidente Schreber ${ }^{30}$.

O conceito de identificação projectiva foi inicialmente proposto por M. Klein, em 1946, baseando-se na experiência da transferência na relação clínica com pacientes psicóticos e tendo por referência as pesquisas sobre os aspectos corpóreos, emocionais e cognitivos da relação entre o infans e a mãe no processo de formação do self, da elaboração psíquica do conceito de realidade e da referência a objectos externos. Na exposição genética do modelo de M. Klein a posição esquizo-paranóide evoluía no sentido da aquisição de um conjunto relacional mais rico ao longo da maturação da imagem infantil da totalidade do corpo da mãe como um objecto situado no meio-ambiente físico, inicialmente percebido como objecto fragmentado. Mas a estrutura mais rica que entretanto emerge conserva a ambivalência "agressão-simpatia" das respostas emocionais do "self arcaico".

Esses movimentos pré-verbais ilustram a organização do que N. Luhmann, num sentido mais amplo, chamou "mecanismo simbiótico" que, no caso da organização da referência do aparelho psíquico ao mundo, acopla o corpo orgânico ao processamento psíquico do sentido e às suas fontes imaginárias. Através da união com as bases fisiológicas da "psyché" têm lugar formas primitivas de comunicação, de natureza corpórea, gestual e manipulatória, que voltam a estar presentes em diversos traços mnésicos nas formas amadurecidas do amor do adulto e que são responsáveis por articular o amor com o sexo, graças à distinção afectiva entre "satisfação / não-satisfação".

O problema central de M. Klein nos seus textos teóricos foi o da caracterização do "self arcaico" e a sua relação com os objectos internos e externos. A psicanalista observou neste self uma deficiente integração de partes assim como tendências alternadas para a integração e a desintegração, que se desenvolvem em conjunção com a evolução das tendên-

${ }^{30}$ M. Klein, "Notas sobre Alguns Mecanismos Esquizóides" in Idem, op. cit., Apêndice, pp. 41-43. 
cias sádicas ${ }^{31}$. A ansiedade é um facto psíquico primitivo que resulta da deficiente integração psíquica do self e da excessiva exposição do eu aos efeitos destruidores da "pulsão de morte". Desta fase são conservados os mecanismos de controlo que reduzem o impacto negativo da ansiedade sobre o eu e que estão voltados para a percepção externa e interna.

A relação com o corpo materno caracteriza-se por movimentos projectivos e introjectivos associados com elaborações psíquicas que canalizam estratégias de controlo e de defesa. Nestes movimentos diferenciam-se processos psíquicos de divisão (e auto-divisão), idealização e negação. O self arcaico orienta a sua relação com o mundo externo de acordo com o investimento libidinal inicialmente voltado para o objecto interno, que é reelaborado no imaginário. Assim, quando o self projecta nos objectos externos partes das imagens mentais do objecto interno é o próprio self que está envolvido nesse processo mediante as marcas da auto-afecção. Ele acaba por se dividir em si mesmo e ele mesmo faz parte da projecção e do objecto projectado.

Dos dados da observação clínica foi possível à psicanalista concluir que no processo de projecção as partes do self projectadas são usadas para controlar ou possuir o objecto "a partir de dentro", originalmente "a partir de dentro" do corpo materno. Explica-se assim que sejam o amor e o ódio as duas principais orientações emocionais na relação do self com as características do objecto interno ou externo sujeitas a projecções ou introjecções. No caso da projecção de partes "más" do self, estas estão dirigidas à destruição ou danificação do objecto "a partir de dentro" ou no sentido da protecção do eu de acções sentidas como agressões. Com os chamados "bons" objectos ocorre algo de semelhante, mas inversamente. O conceito completo da "identificação projectiva" inclui o reconhecimento dos "bons" e dos "maus" objectos e das partes "boas" e "más" do self.

O objecto amado é percepcionado como uma extensão do "bom" self. A idealização é uma consequência comum da relação arcaica com o bom objecto (interno ou externo) e é muito comum nas descrições da paixão e nas histórias de amor de personagens adultos. O caso da descrição da paixão da autora implícita das Cartas Portuguesas é um exemplo. Adicionalmente, deve referir-se que é possível que a base narcisista da coesão do self se empobreça pelo uso excessivo de identificações projectivas. A ilustração com a novela de Julian Green, Fabian, no artigo de M. Klein sobre Identificação, de 1955, vai aprofundar esta questão.

As referências ao texto de Freud sobre a "Psicologia de Grupo e a Análise do Ego" e às ideias do pai da Psicanálise sobre o amor tornam evidente três características psicológicas nas relações passionais: a iden-

${ }^{31}$ Cf. Idem, Ibid., in Idem, op. cit., pp. 25-27. 
tificação, a projecção e a idealização ${ }^{32}$. Sob influência da sua doutrina sobre as fixações narcísicas da libido Freud disse que o objecto idealizado da paixão é tratado como o nosso próprio ego. Assim, deve afirmar-se que amamos o objecto como a nós mesmos. M. Klein anexa ao pensamento de Freud sobre a identificação narcísica a ideia de que o objecto amado tem de corresponder a uma parte do self cindido e expelido na estra-tégia de conservar o ego e o bom objecto interno de agressões eventuais. O sentido narcísico da identificação projectiva mobiliza as três orientações da identificação, da projecção e da idealização como meios de assegurar a auto-reprodução do self como unidade-psíquica-objecto-de-amor. Por sua vez, J. Lacan, no Seminário sobre a Identificação (sessão de 6 de Dezembro de 1961), havia insistido na tese de que a identificação não significa simplesmente o "tornar-se um" e que a identidade só pode formar-se mediante a diferenciação e tomando sempre esta alteração do mesmo como a referência designadora do mesmo. Ora, esta última perspectiva leva-nos à ideia de um corredor contínuo de posições deslizantes entre o plano em que se desenrola a experiência psíquica da identificação, como experiência interna do self, e o plano da concretização nos objectos externos e na interacção com outrem dos processos imaginários de identificação.

Depois de M. Klein, W. R. Bion (1959) ensaiou a descrição do processo de re-introjecção de uma projecção inicial depois de uma captura bem sucedida do objecto "desde o interior" como fase terminal da sequência da identificação projectiva ${ }^{33}$. Podemos daqui inferir que nos casos das relações amorosas a fase da re-introjecção ocorre através da co-referência do amante e da amada que se torna progressivamente um meio auto-referencial de coordenação de aç̧ões e emoções.

Quando o self se identifica com aspectos ou com a totalidade de objectos na vivência psíquica não descrevemos este nexo como um "splitting off" típico da identificação projectiva mas inversamente como uma identificação introjectiva. De acordo com a interpretação de J. Sandler das ideias de M. Klein a identificação projectiva supõe dois aspectos unidos na "forma da representação" e um movimento projectivo: a auto-representação, a representação do objecto e a projecção da primeira na segunda ${ }^{34}$. A projecção é a atribuição a uma representação do objecto de aspectos da auto-representação do eu. O mecanismo que assegura um movimento nos dois sentidos envolve a posição do que J. Sandler chama fronteiras

${ }^{32}$ M. Klein, "Sobre a Identificação" in Idem, op. cit., p. 174.

${ }^{33}$ W. R. Bion, "Ataques ao Elo de Ligação" in E. B. Spillius (ed.), Melanie Klein Hoje, Rio de Janeiro, 1991, pp. 95-109, especialmente pp. 103-104.

34 J. Sandler, "The Concept of Projective Identification" in Idem (ed.), Projection, Identification, Projective Identification, London, 1989, (reed. 2004) pp. 13-26. 
entre o objecto e o self, a representação do objecto e a representação do self.

Os teóricos pós-kleinianos, entre os quais D. Meltzer, referiram a dualidade do "eu" e do "não-eu", a faculdade de formar símbolos e conceitos, a distinção entre objectos reais e ilusórios, o estado de espírito e as polaridades afectivas da simpatia-antipatia e ainda a imagem da identidade pessoal como processos associados à identificação projectiva. Quer dizer que é a coesão do aparelho psíquico e a sua autopoiesis que aqui está em jogo. Nos seus estudos escolhidos incluídos no volume Claustrum, D. Meltzer expandiu o significado da identificação projectiva de modo a incluir relações de objecto e relações consigo mesmo do eu reveladoras de estratégias de "insinuação na mente de outrem", interacções e relações comunicativas ${ }^{35}$.

A relação consigo mesmo do eu está orientada de tal modo que a comunicação está sempre presente, mas apenas como "imagem" no processo de reprodução do self e na reprodução dos mecanismos responsáveis pela adaptação ao meio.

Os acontecimentos comunicativos propriamente ditos que se dão no meio-ambiente dos sistemas psíquicos contam, para estes, apenas como construções figurativas da consciência ou imagens ou seja, segundo a auto-referência do sentido psíquico. Na identificação projectiva a diferença entre o interior e o exterior torna-se central e esta distinção é ainda o modo propriamente psíquico de representação do meio-ambiente e da relação entre sistema e meio. Para os sistemas psíquicos, a referência à comunicação tem se de dar, igualmente, à luz desta polaridade do interior e do exterior. É assim que a comunicação e a interacção comunicativa "entre presentes" se tornam aspectos desse imenso exterior, o "de fora", da referência dos sistemas psíquicos.

No entanto, nunca será possível descrever a comunicação como uma extensão de elementos da vida psíquica e em parte justamente em virtude da descrição convincente de Freud da fundação narcísica das relações de objecto e das relações de amor na fórmula amamos o objecto como a nós próprios.

Como espaço não-marcado, este imenso "de fora" das vivências psíquicas, da corrente de consciência, depende da organização auto-referencial da vida psíquica relacionada com o equilíbrio emocional e cognitivo, a auto-reprodução do self e a distribuição dos sistemas psíquicos em formas individualizadas do processamento do sentido psíquico: os sistemas psíquicos são sempre plurais e descontínuos.

Isto quer dizer que do ponto de vista psíquico da "identificação projectiva" o self está voltado para a comunicação e a interacção com o

35 D. Meltzer, The Claustrum. An Investigation of Claustrophobic Phenomena, London, 1992 (reed. 2008). 
propósito do "controlo psíquico" sobre "pessoas" ou sobre "este" outro em particular. Esta operação psíquica de controlo está presente mesmo se o controlo é ilusório e, seguramente, ele é sempre ilusório.

Recentemente reavaliado na obra de T. Ogden (1982) o mecanismo psíquico da "identificação projectiva" pode descrever-se nos pólos chamados "projector" e "recipiente" ao longo de uma sequência de fases ${ }^{36}$.

A primeira fase é descrita como um acto inconsciente de projectar em outra pessoa representações dos objectos internos do eu e as representações associadas do self, de tal modo que as partes projectadas se tornam componentes da outra pessoa e, aqui, responsáveis pela explicação de aspectos do seu comportamento. A segunda fase está essencialmente relacionada com expectativas e pressões para a acomodação do comportamento alheio às expectativas do eu relativamente ao significado das partes projectadas do "projector". A fase final representa a re-entrada das partes projectadas observadas no comportamento alheio na "consciência do eu" e respectiva imagem do processamento psíquico do sentido.

A projecção é sempre imaginária mas desenvolve-se na interacção com outrem através de expectativas que mobilizam símbolos e referências baseadas na comunicação. Estas "extensões" colocam uma complexidade suplementar no mecanismo projectivo de base e desenvolvem-no para operações que já não se podem considerar exclusivamento no plano do "pensamento". De facto, de acordo com a Teoria dos Sistemas trata--se aqui de elementos da comunicação que estão conectados uns com os outros através de sequências comunicativas que se auto-pressupõem e que são autónomas relativamente a qualquer influência "psíquica" directa.

Pode provisoriamente concluir-se que a distribuição dos sistemas psíquicos em indivíduos envolve a consequência paradoxal de a orientação psíquica para outrem não se poder concretizar exclusivamente por meios psíquicos. A tentação de chegar até à vida psíquica alheia usando meios psíquicos como a identificação projectiva termina com a evidência de que essa vida psíquica é, precisamente, outra. Por isso, no amor, $o$ outro-amado da representação psíquica do amor sou sempre eu próprio, o eu do ego-actor, a que se referia N. Luhmann. A individualidade numérica dos sistemas psíquicos faz deles unidades fechadas de sentido psíquico que só podem abrir-se a outras unidades graças a um salto na comunicação. As projecções com sentido identificatório levam as unidades psíquicas até ao limite do que cada um pode alcançar de outrem com recurso ao "pensamento".

36 T. H. Ogden, Projective Identification and Psychotherapeutic Technique, New Jersey, 1982, pp. 11-37. 
Nas experiências não-patológicas da identificação projectiva cada um aceita participar até um certo ponto num jogo de defesa e controlo através de uma variedade de combinações das auto-representações e das representações de objecto. Este jogo desenvolve-se no suposto de limites muito difusos e móveis entre elementos conscientes e inconscientes. A eficácia do jogo e as condições para a sua observação dependem de um número muito reduzido de participantes, um conhecimento mútuo adquirido na interacção e uma aceitação tácita no sentido de influenciar ou deixar-se influenciar. A relação amante-amada representa um jogo dotado destas condições. Assim, sob a reserva da autonomia sistémica dos sistemas psíquicos e da comunicação pode acrescentar-se ao esquema inicial de N. Luhmann em Liebe als Passion as polaridades do "projector" e do "recipiente" da identificação projectiva na reformulação de T. Ogden.

Acção: Projector (I. P.) - EGO amante $\rightarrow$ acções no sentido de se revelar a si mesmo para o objecto de amor com "este ou aqueles predicados"

Vivência: Recipiente (I. P.) - ALTER no lugar da(o) amada(o) $\rightarrow$ vivência do amor com "este ou aqueles predicados"

(I. P. - "Identificação Projectiva")

Em alguns casos, podem considerar-se condições auxiliares para assegurar a limitação do número de participantes o desenvolvimento do jogo num espaço circunscrito, o equivalente ao claustrum - convento ou instituição religiosa votada à clausura, associações voluntárias "intra muros", a casa ou o escritório. O meio ambiente espacial e a referência arquitectónica torna-se um "mecanismo simbiótico" adicional. O comportamento dos participantes do jogo deve exemplificar o uso de observações de primeira ordem relativamente aos papéis que cada um assume sob influência dos items projectados pelo outro. Observações de segunda ordem que conduzem ao completo reconhecimento da situação cancelam a eficácia do jogo.

O acoplamento dos elementos psíquicos com os comunicativos é assegurado através do duplo meio ambiente dos sistemas psíquicos e da comunicação. Mas este duplo meio-ambiente não é um domínio homogéneo e contínuo. A hipótese do duplo meio ambiente implica pelo menos uma dupla perspectiva sobre o que „ocorre“. Assim, o acesso a „eventos“ é sempre bifacial: do ponto de vista do espaço marcado da comunicação ou a partir da auto-pressuposição psíquica.

Os mecanismos da identificação projectiva foram inicialmente tratados como mecanismos psicológicos. Mas eles estão forçosamente articulados 
com operações comunicativas numa grande variedade de interacções. Isto pode ser formulado do seguinte modo: o que eu sinto a meu próprio respeito através dos objectos amados / odiados motiva aspectos das estratégias comunicativas na interacção com outrem, cujos efeitos eu não posso dominar com meios psicológicos.

Do lado dos sistemas psíquicos, a identificação projectiva assegura uma ilusão convincente de um controlo sobre temas da comunicação e um escudo protector contra surpresas. Do lado da comunicação, a expansão ou alimentação da comunicação através de projecções assegura a capacidade de auto-identificação dos grupos ou contribui para o reforço da coesão interna das redes de interacção através da reprodução de padrões. A reprodução de expectativas cognitivas e normativas na comunicação está associada a esta coesão. Mas os fenómenos de crise ou de uso violento da comunicação também ocorrem. Sob pressão de projecções as estratégias comunicativas podem evoluir para a polarização dos temas da comunicação ou das formas de tratamento dos emissores e destinatários da comunicação em torno dos pólos amor-ódio. Esta sobreposição pode conduzir a consequências auto-destrutivas no horizonte da comunicação de grupo, na comunicação familiar ou na comunicação a dois.

A distinção entre o "de dentro" e o "de fora" ocorre na relação entre os sistemas psíquicos e o meio ambiente mas também na auto-referência da "casa". Em "casa", "em família" ou no claustrum as relações mútuas entre membros estão orientadas num reduzido micro-cosmos em que cada um tenta manter controlo sobre os restantes com recurso às extensões comunicativas das identificações projectivas, mas sempre dentro dos limites das vivências psíquicas próprias. $\mathrm{O}$ espaço circunscrito é a réplica física da limitação do raio de alcance da identificação projectiva.

Foi uma parte disto o que N. Luhmann pretendeu significar com a aplicação da categoria sistémica da "interpenetração" ao amor romântico e, adicionalmente, à comunicação familiar. Escreveu no capítulo final de Liebe als Passion que o amor está voltado para o mundo e para os elementos dos outros sistemas psíquicos de tal modo que o amante se torna parte do seu objecto de amor. Contudo, sendo outro sistema psíquico o objecto de amor simplesmente não está em repouso. Ele assimila as operações do seu-outro e modifica-se ele próprio através desta assimilação do que ficcionou do outro. O "amor" e o "amor romântico" como um código simbólico comporta esta regra central: alguém assume uma atitude, uma iniciativa, na interacção, cujo sentido se descobre somente, sempre, através das vivências (Erlebnisse) psíquicas do outro.

Esta dualidade de acção e vivência explica por que motivo o código do amor da sociedade moderna não desemboca em nada de equivalente a uma unio mystica dos amantes, como aconteceria com a redução do 
"amor como paixão" a uma experiência exclusivamente psíquica, como adiante veremos, mas supõe a separação entre "pessoas" como "agregados de auto-referências" ou expressões da interpenetração sistémica.

Nos sistemas da intimidade ou no que chamamos "família" a interpenetração significa uma associação de elementos psíquicos e comunicativos, distintos do ponto de vista sistémico, destinada à fixação de acoplamentos ou à reprodução dos produtos de acoplamentos. No caso da comunicação amorosa a interpenetração tem de se dar na relação assimétrica entre ego-acção e alter-vivência a que se sobrepõem observações mútuas e antecipações de percepções mútuas. Mas posso agora acrescentar que o mecanismo da identificação projectiva é um importante aspecto do enlaçamento dos elementos psíquicos com as formas da comunicação amorosa, na interpenetração, tomando-se o "lar" como forma de concentração das relações. A "casa" é um claustrum normalizado por hábitos, em que se estabelece um campo fechado adaptado a uma comunicação com um número limitado de participantes sobre um conjunto indefinido de temas ${ }^{37}$.

Reconstruindo agora para o meu objectivo o uso do termo claustrum por D. Meltzer a propósito da experiência analítica eu diria que o "lar" moderno, identificado com o espaço fechado dos sistemas da intimidade da sociedade moderna, é um claustrum normalizado segundo uma aplicação expandida dos símbolos que correspondem à atmosfera emocional do "amor romântico" que, inicialmente, apenas incluía o par de pessoas do ego-amante e de alter-amada. É a partir da referência ao seu claustrum emocional e ao claustrum arquitectónico que os membros da família podem ser o que são: um número limitado de emissores e destinatários da comunicação íntima.

Há ainda uma outra significação do claustrum no caso da história de Mariana. A clausura é também segredo. A forma do segredo aproxima-se da forma da intimidade do lar sem se confundir com esta. O espaço confinado pode referir-se a uma protecção contra intrusos, a uma concha. Esta é, de facto, uma condição das relações íntimas. A arquitectura pode descrever fisicamente o limite frente ao exterior, ao mundo público, mundo do trabalho ou mundo político. Mas refere, também, aquilo que está ao abrigo da curiosidade e que deve, portanto, manter-se à margem de um critério público do verdadeiro - falso. O claustrum pode então não designar o lar, mas mais geralmente o domínio circunscrito ao abrigo da verdade em sentido público. Sabemos pelas Cartas que aquele amor da irmã de Beja estava destinado a ser escandaloso. Tudo nele conduzia ao escândalo, desde a diferença na condição nacional dos amantes, ao desnível social presumível, até à condição de consagrada da

${ }^{37}$ N. Luhmann, "Sozialsystem Familie” In Idem, Soziologische Aufklärung, Bd. 5 Konstruktivistische Perspektiven, Wiesbaden, 20094, pp. 189-209, especialmente p. 199. 
reclusa. Se sublinhamos este carácter escandaloso descobrimos a razão de um claustrum de segredo no amor de SMA e vemos como as Cartas se transformam num acto de confissão com uma tripla referência ao recolhimento: o local secreto dos encontros de amor mistura-se com o claustrum psíquico-confessional do encerramento na escrita e ainda com o espaço de reclusão religioso. Estas três são as possibilidades reais do espaço da história de SMA que se articulam e ganham a sua densidade própria frente à possibilidade apenas virtual do espaço do lar. Percebemos que o amor talvez possa estar condenado ao segredo ${ }^{38}$, a um tipo de intimidade mais íntimo que o lar, e que a inefabilidade a que se refere a sua mitologia seja afinal apenas a indicação de que a paixão fala para além da verdade e da falsidade.

\section{Escrita da Consciência, Silêncio da Comunicação e Mística}

As Cartas Portuguesas não se limitam à confissão de amor, mas narram uma história que nos leva forçosamente a imaginar um tempo e um espaço e à identificação de protagonistas dessa história. $\mathrm{O}$ género literário epistolar tem esta característica de poder sugerir uma história narrada pelos emissores das cartas cujo valor documental está sempre situado entre ficção e realidade histórica.

Por outro lado, nas "cartas de amor" o género epistolar evidencia a assimetria da relação passional graças a um tipo de comunicação que parece estruturado de modo a impedir essa assimetria e a assegurar, pelo contrário, a troca e a permuta de posições numa reciprocidade aparentemente perfeita.

Do ponto de vista literário, o tipo epistolar específico das "cartas de amor" cria uma atmosfera de intimidade entre o leitor e os autores virtuais das cartas. Esta sugestão de intimidade corresponde a uma forte aparência de veracidade e autenticidade que se deve ao facto de o leitor pretensamente aceder sem mediações ao que cada um dos emissores enuncia sobre si numa relação de suposta franqueza e é ainda mais vincada pelo facto de cartas como estas deverem exprimir particularidades da vida privada e íntima, que não se revelam em público. A verosimilhança dos elementos biográficos comunicados é neste sentido intensificada e daqui se infere, mediatamente, o valor de verdade das proposições epistolares com referência situacional, temporal e espacial. As "cartas" não são usa-

${ }^{38}$ A este respeito V. Aubert em The Hidden Society (1965), New Jersey, 1982, referia no amor uma "normalidade do segredo" (p. 204) e concebia a literatura sobre o amor como uma forma de tornar público o que há de mais privado (p. 207). 
das apenas como "provas" sentimentais mas também como documentos sobre acontecimentos. No entanto, ao mesmo tempo que põem no seu centro a referência empírica da história narrada ou pressuposta tornam essa referência imprecisa, pois a articulam com um dizer subjectivo. Desta imprecisão da referência resulta a sua indecidibilidade. Sabemos que da imprecisão e da indecidibilidade da referência, da referência autoral, neste caso, se alimentou a ficção sobre a "Soror Mariana Alcoforado" como autora empírica, de facto e de jure, quer dizer segundo um "registo oficial", das Cartas Portuguesas. O "mito nacional" que se formou nestas condições e que se adensou com apreciações relativas ao que deve ser suposto "português" em relação com o "de fora" é bastante evidente na obra do biógrafo L. Cordeiro ${ }^{39}$.

Como vimos, este último atribuiu a autoria das Cartas a uma freira de Beja, que ele identifica com a Soror Mariana Alcoforado (ou Alcoforada), sem aspas, "em pessoa".

Para sustentar a sua tese do ponto de vista da análise estilística das próprias Cartas teve de referir uma oposição entre o "castiço", português, feminino, inocente e imaculado e o libertino, refinado, polido, amaneirado, astuto e cheio de subentendidos típico da cultura de salão e do gosto mundano parisienses. Esta oposição é mantida ao longo das suas reflexões a que acresce a diferença entre a escrita feminina e a masculina. Para justificar a atribuição das Cartas à freira SMA Luciano Cordeiro não só tem de forjar o sentido destas oposições como ainda alinhar a escrita de SMA em um dos lados. Em última análise este alinhamento bipolar cria a oposição entre a figura do libertino (francês) e a da mística (portuguesa) e é segundo as normas ditadas por este registo opositivo que ele pode criar a identidade Mariana Alcoforado.

A ausência de estilo artificial e refinado, o escrever directo e franco e o falar "desde o coração" seriam as características mais salientes do texto de SMA-Mariana Alcoforado. Daqui parte o biógrafo para uma das suas teses que diz que só uma mulher de determinada condição cultural média, com espírito ingénuo e inocente, podia ter escrito aquelas epístolas. Sucumbe, pois, à tentação de atribuir ao autor empírico das Cartas tudo o que descobriu no autor implícito das mesmas.

Estas imputações e a falta de esclarecimento da diferença entre autor implícito e autor empírico conduz ao tema da atitude mística real da freira portuguesa. A referência à escrita das místicas está numa comparação com escritos de outras freiras portuguesas como Madre Mariana da Purificação e as descrições do que L. Cordeiro considerou ser o "sensualismo místico". A escrita de SMA aproximar-se-ia, assim, da escrita simples, ingénua e

${ }^{39}$ L. Cordeiro, Soror Mariana, a Freira Portuguesa, Lisboa, $1890^{2}$, op. cit. 
directa das místicas, o que, para ele, era mais uma prova de que a autora só poderia ter sido uma (aquela) religiosa portuguesa.

A história de amor das Cartas Portuguesas narraria então o rapto emocional de uma mulher mística, pura e ingénua, por um libertino francês, cínico e sem escrúpulos. Sem se aperceber L. Cordeiro pode dar razão aos que não desdenhariam colocar as Cartas entre os títulos da literatura libertina francesa, de tal modo condiciona a construção do "sensualismo místico" da mulher portuguesa, humilde e subalterna, pela imagem inversa do cavaleiro libertino como dois pólos de uma só trama, no desenvolvimento lógico da sua narrativa.

A ideia de um "sensualismo místico" torna-se tão central que o biógrafo concebe uma autêntica corrente mística dentro do Convento de Beja que afecta um conjunto de personagens femininos ali reclusas. Numa passagem alude ao clima de misticismo sensual típico da vivência das freiras do Convento, relatando alguns casos.

N'estes registos, mais ou menos longos, das pre-destinações conventuaes, vemos passar muitas das companheiras de Marianna Alcoforado, sem que o nome d'esta, já no começo do século XVII aureolado entre ellas, pelos clarões da redempção penitencial, uma só vez appareça: - são Catharina de Aragão, - a da citação que acabámos de fazer; Marianna da Conceição, - a "que sentindo nunca consentiu»; - Anna Maria de Santa Thereza, - a que se flagellava na capella do Capitulo; - Guiomar de Jesus, - «solitária contemplativa sempre elevada na contemplação da celestial formosura»; — Ignez de Christo, — «tão silenciosa que ninguém sem urgente necessidade lhe ouvia falar»; - Leonor dos Martyres, - muito dada a ver extraordinárias coisas, chegando a ver um dia no coro "um homem com outro ás costas», visão perfeitamente explicada pela mystica conventual; - Maria de Jesus, - cheia de «toques e moções interiores»; - uma abbadessa, que por nome não perca, que oppondo-se á construcção de uma capella do Baptista, indo ás três horas da madrugada para o coro, encontrou, nem mais nem menos, do que «um homem venerando, vestido de pelles .... ${ }^{40}$

Entre as Carmelitas do Convento da Esperança vivia uma Madre Mariana da Purificação de que se conhecem descrições de viva sensualidade mística como aquela que o biógrafo também cita.

Baques e abalos que o coração me dá no peito, - diz ella própria, - que o ouço com os ouvidos corporaes e desejo abrir o peito com as

40 Idem, Ibid., p. 194. 
minhas próprias mãos, e deixai-o voar para onde elle quer e deseja tanto, mostrando que não quer viver em mim senão no seu centro que é o meu Divino Esposo ${ }^{41}$.

A combinação dos excessos historicista, biografista e nacionalista no comentário de L. Cordeiro leva apressadamente a conceber SMA como a autora empírica das Cartas. O interessante que temos a apontar é que estamos aqui perante um modo de conceber o referente-autor exemplificativo de um mecanismo de identificação em que o biógrafo fica aprisionado sem se dar conta disso, de uma identificação com a virgem-em-rapto-de-amor-com-o-cavaleiro-sedutor-francês que mima na forma psicológica do sentimento a condição subalterna do "destino português" entre as nações civilizadas.

O que a esta distância histórica nos parece adequado é sustentar que a sua narrativa descreve o autor implícito das Cartas, revela de modo especialmente claro que "situação pressupositiva" deve o leitor associar ao emissor desses textos. Mas, é evidente que, aqui, o emissor é uma criação da comunicação textual e não necessariamente uma freira de carne e osso. Ao fantasma autoral constituído pelo reconhecimento da "situação pressupositiva" textual relativa ao autor implícito das Cartas proponho continuar a chamar "Soror Mariana Alcoforado" (SMA). Todavia, é claro que entre o autor-fantasma e o autor-empírico se desenrola um corredor virtual $\longrightarrow \longrightarrow$ real de identificações e projecções, que a hipótese místico-sensualista do biografismo nacionalista intensifica quando o biógrafo se identifica ele mesmo, na sua condição lusa, com o destino da infeliz Soror.

Nas cinco cartas publicadas em Paris em 1669 pelo editor Claude Barbin lê-se a experiência intensa da paixão amorosa da autora implícita, SMA, promessas de amor eterno, a devoção ao cavaleiro francês, destinatário e primeiro leitor implícito das cartas, e o desenvolvimento de um estado de espírito que evolui desde a exaltação, à ansiedade até à depressão. SMA censura até certo ponto no seu objecto de amor a causa do seu estado amoroso para logo abandonar a atitude de reprovação e se afirmar pronta a todo o sofrimento como se este fosse um estado bem-aventurado. A escrita está construída nesta oscilação entre os valores diferenciais do paradoxo do "sofrimento fecundo" por amor: entre a ferida e a passividade da afecção amorosa e a iniciativa de querer prolongar o amor; depressão e ansiedade. A retórica barroca das Cartas, não obstante a simplicidade do estilo, desenvolve-se em sequências depressivas ou ansiosas sem conseguir desatar o nó do paradoxo da ansiedade e da

${ }^{41}$ Idem, Ibid., p. 196. 
depressão até à quinta carta que representa, a meu ver, uma passagem da beleza do erotismo no sublime.

Monólogo, confissão ou novela epistolar, as Cartas Portuguesas são, antes de tudo, um exemplo de comunicação do self ou $d a$ consciência no seu fluxo. A estrutura epistolar da comunicação do self introduz, contudo, um nível adicional de complexidade ficcional, pois todas as cartas, e as cartas de amor de um modo ainda mais evidente, são, por excelência, comunicação com o ausente, com o ilusório, com o fantasma. Por outro lado, elas são já invocação do outro absoluto quando se insinua a suspeita do vazio na réplica. Então, nelas, a forma geral da comunicação entre o emissor e o destinatário serve o propósito de engendrar uma relação com o self através de um jogo ficcional com o destinatário como „recipiente“ de projecções e de identificações projectivas.

Para entender como se estrutura a relação entre emissor e destinatário num plano simétrico ao da relação entre projector e recipiente é necessário tomar a relação comunicativa das Cartas como o objecto de análise e não os seus conteúdos históricos ou biográficos "reais".

O jogo ficcional das Cartas representa uma forma tentada mas não concluída de "identificação projectiva". Clarifiquemos esta ideia-guia.

As primeiras Cartas descrevem o começo da afecção amorosa e, seguidamente, concentram-se na atribuição das características do "bom" objecto interno ao amante. A intenção é tomar "por dentro" o objecto de amor por meio de uma devoção sem limites em que se ama o objecto "como a nós mesmos". Mas tudo se desenvolve no domínio da "corrente de consciência". Na forma da vivência SMA reproduz o que lhe aconteceu de modo a "agir" pela escrita. Esta é a sua única forma de acção, aliás inteiramente concordante com o fluir da consciência e das vivências. SMA explica como não pode viver sem a sua relação com o objecto de amor; ela própria está nessa relação, por dentro dela, apropriando a coisa para si mesma e revendo-se nela como na sua imagem mais querida. Mas rapidamente nos apercebemos que as Cartas são sem resposta e que o silêncio representa a recusa de um comportamento em conformidade com o pedido da confirmação do amor. As projecções não correspondem a acções do lado do destinatário nem sequer na modalidade de acções da consciência como a escrita de outras cartas de amor. As várias referências ao cruel silêncio do cavaleiro francês permite aos leitores, que somos nós, perceber que se trata de um caso de rapto emocional, de uma afecção que permanecerá imaginária até ao fim, de um caso de amor auto-referente ou, justamente, de uma projecção que tem nas Cartas o seu único documento.

Nas primeiras cartas assiste o leitor à representação de um drama psíquico-comunicativo no sentido de desenhar as condições de projecção do 
"bom" objecto da freira no destinatário. Esta representação tem por referentes pólos exclusivamente virtuais: no emissor-autor implícito (SMA) e no destinatário-leitor implícito de primeiro grau (o cavaleiro francês).

Podemos suplementar os dois esquemas anteriores com as polaridades comunicativas acabadas agora de referir.

Re-entrada da vivência na acção: Projector (I. P.) - EGO amante / emissora-autora implícita $\rightarrow$ escrita, como imagem da consciência, no sentido de se revelar como a amante feminina do objecto masculino de amor

Vivência: Recipiente (I. P.) - ALTER como objecto de amor / destinatário-leitor implícito de primeiro grau $\rightarrow$ vivência masculina do amor de uma amante devota, na forma do silêncio.

(I. P. - "Identificação Projectiva")

As Cartas Portuguesas representam a tentativa de carácter ficcional no sentido de seduzir e submeter o destinatário a um compromisso com o amor o que, a concretizar-se, significaria a aceitação de agir em conformidade com as partes projectadas de ego sobre alter, no equivalente a um pacto identificatório.

SMA não chega verdadeiramente a comunicar. Ela torna a sua consciência transparente, escrevendo, usando a "carta" como forma de revelar as vivências. Esta escrita da consciência é, por isso, num elavado grau, projectiva. Quem paradoxalmente produz efeitos no plano da comunicação é o cavaleiro francês. É o seu silêncio que instaura o domínio comunicativo como sepulcral, como um sistema diferente das vivências da consciência.

Mas, criando no destinatário das Cartas um recipiente de projecções da sua escrita da consciência SMA entra num colóquio ficcional com ela própria, com a sua paixão espectral. A instauração do domínio da comunicação pelo cavaleiro francês, como domínio mudo, como âmbito da não-resposta, revela ainda mais a circularidade auto-referente da consciência e da sua escrita. Através da escrita das cartas de amor SMA endereça as suas projecções a um ausente que não se quer fazer presente, mostrando com isto o seu carácter circular, mas é claro que isto só se revela pelas próprias Cartas, e enquanto acto de escrita, e pelo tipo de ficcionalidade que elas garantem e não por um silêncio fáctico: o silêncio da comunicação é o silêncio que a escrita da consciência retém sobre a ausência de comunicação, o que novamente dá prova da auto-referência do sistema psíquico projector.

A escrita revela como a paixão estabelece um nexo de causalidade circular entre a posição inicial do ego-projector e o mesmo sujeito no ponto de chegada da relação como mecanismo de controlo dos efeitos das 
partes projectadas. A ficcionalidade de segundo grau do género epistolar torna possível que todo este processo se desenvolva sempre dentro da ficção e como ficção da consciência projectora.

Do ponto de vista temporal, a sequência das Cartas, como fluxo escrito da consciência, estabelece progressivamente a sintonia entre o desenvolvimento psíquico da projecção e a percepção interna do muro na comunicação. Revejo aqui um outro efeito do claustrum.

$\mathrm{Na}$ forma epistolar, esta sintonia tem de ser marcada como sintonia $d a$ consciência. Ela ocorre quando o silêncio do cavaleiro francês se torna vivência psíquica em SMA. O sentido do movimento entre os dois pólos do projector e do recipiente estabelece-se então no que deve ser a sua consequência para ego-projector.

A descoberta da dificuldade e por fim da impossibilidade de tomar posse do objecto de desejo, na fala ou escrita do oficial francês, "por dentro" dele, converte a tonalidade emocional da orientação inicial para o objecto da paixão. De um inequívoco "bom" objecto ele torna-se, para o fim das Cartas, na coisa "odiada".

Esta conversão é justificada quase abertamente por SMA: a corrente psíquica da projecção não produziu os correspondentes (e esperados) efeitos comportamentais e comunicativos no recipiente. Literalmente, a corrente projectiva da consciência foi bloqueada no recipiente por ausência de resposta na comunicação.

Assim, os três graus da identificação projectiva referidos na sequência de T. Ogden estão todos presentes no caso da paixão de SMA mas graças a uma re-entrada imaginária. A comunicação epistolar como escrita da consciência garante a ilusão da comunicação mas serve também para mostrar que a comunicação não chegou a ter lugar. As respostas do oficial francês são representadas como citações ou referências oblíquias no texto de SMA, o que reforça o seu valor espectral.

A informação sobre a ausência de resposta factual é obtida apenas em "cartas". É, pois, como referência epistolar, uma construção epistolar.

A ausência factual da comunicação é referida pelo menos de duas formas. De um primeiro modo enquanto causa da escrita das cartas, constatando-se a partida do cavaleiro francês e, por conseguinte, constituindo-se o "ausente" em destinatário. A ausência é causa da escrita. De uma outra forma para identificar o motivo da mudança de tonalidade afectiva na relação amor / ódio, na parte final. Nos dois modos há re-entrada da hetero-referência na auto-referência psíquica. Na primeira modalidade as vivências psíquicas referem-se ao meio-ambiente físico; na segunda ao meio-ambiente da comunicação. Do ponto de vista temporal, a primeira referência estabelece-se na memória, mas a outra na actualidade da corrente da escrita da consciência. A polaridade ausência/ presença tem 
também significados diferentes consoante o meio-ambiente que se tomar como referência e está associada a tonalidades emocionais distintas.

Graças à estrutura da comunicação epistolar a ausência do cavaleiro francês do meio-ambiente físico de SMA reflecte-se na sua re-entrada como destinatário, mas além disso conduz também ao alinhamento da maior parte dos aspectos categorizáveis sob o "mau" objecto da paixão e como tal projectados pelo ego-emissor.

A relação com o objecto de amor in absentia é um dos motivos para os paradoxos que atravessam a escrita. Veja-se este exemplo: Je résiste à toutes les apparences, qui me devraient persuader que vous ne m'aimez guère, et je sens bien plus de disposition à $m$ 'abandonner aveuglément à ma passion, qu'aux raisons que vous me donnez de me plaindre de votre peu de soin $^{42}$.

A enunciação paradoxal é inevitável na estrutura das Cartas. Os paradoxos estão ancorados na forma da relação com o objecto do amor in absentia representado como objecto negativo: o amante cínico como destinatário silencioso. A comunicação com o destinatário que recusa a resposta mostra a forma do desejo de SMA em que a forma da comunicação está encapsulada e adere totalmente ao movimento do desejo psíquico até ao seu referente, embora sem tomá-lo „por dentro “. Como veremos mais adiante, esta forma do desejo, que agora identificámos, é a forma do desejo absoluto.

A paixão é alimentada através do desnível entre o objecto do amor como parte do self e esse objecto como destinatário de "cartas": como parte do self ele é investido como o "bom" objecto inicial; como destinatário ele é o inacessível, o eco sem resposta da comunicação ou ainda o "mau" lado do objecto perdido. Como já disse, esta forma paradoxal do desejo de SMA reside no facto de a estrutura da paixão estar associada à reprodução deste duplo sentido do objecto e à sua re-entrada no lado da comunicação assim como no lado da consciência. O "mau" lado e o "bom" lado do objecto do desejo são revelados através da expressão epistolar da paixão e pela memória reprodutora.

A forma epistolar da comunicação articula a identificação projectiva exactamente por meio das duas polaridades do "bom" e do "mau" objecto ao associar o "mau" à forma da comunicação in absentia e o "bom" objecto à memória da relação passada. Assim, na escrita, a forma da comunicação serve de moldura de manifestação e de projecção do "mau" objecto.

No objecto perdido identificado com o destinatário, SMA lança todos os predicados que a descrevem a ela como um indivíduo miserável, dividido, dejecto. No mesmo objecto mas concordante com a informação

42 Lettres Portugaises traduites en François, Troisième Édition, à Paris, chez Claude Barbin, 1672, pp. 79-80. 
mnésica virtual são lançados os predicados que a realizam e tornam completa e harmoniosa.

A relação completa consigo mesma e com os despojos mnésicos do "bom" objecto depende da actualização da forma da comunicação epistolar, incessantemente, mas para, nesta repetição, ela se descobrir, uma vez mais, dividida e incompleta. Sempre que pela forma da comunicação epistolar se actualiza a relação in absentia com o destinatário a relação da consciência com o seu "bom" objecto entra no domínio das formas virtuais, espectrais - o objecto de desejo só se revela como um destinatário de cartas, mas como um destinatário ele tem de surgir como objecto perdido.

$\mathrm{O}$ embutimento da distinção psíquica entre actualidade e potencialidade na diferença comunicativa do emissor e destinatário exprime bem a combinação do processamento psíquico e do processamento comunicativo do sentido da paixão de SMA, mas mediante um acoplamento em que nenhum dos dois se deixa determinar exclusivamente pelo outro.

A quinta carta começa e conclui-se com a convicção da impossibilidade de uma resposta positiva da parte do oficial francês. Ela refere-se ao fim do amor e à passagem a um ódio provisório. $\mathrm{O}$ destinatário da comunicação é cada vez mais identificado com o "mau" objecto. No entanto, é tambem nesta carta final que SMA declara algo de sublime. Ela apercebe-se, por um lado, que não pode cumprir o desejo da mulher simbolicamente representado pela aliança matrimonial. Isto mostra até que ponto ela fica ferida na sua condição de mulher.

Ela escreve que o importante é a paixão e que a paixão é mais valiosa que o seu objecto: J'ai éprouvé que vous $m$ 'étiez moins cher que ma passion et $j$ 'ai eu d'étranges peines à la combattre, après que vos procédés injurieux $m$ 'ont rendu votre personne odieuse $e^{43}$.

Com a declaração de SMA do seu ódio ao "mau" objecto da sua paixão acabam também as Cartas. Depois da conclusão vos procédés injurieux $m$ 'ont rendu votre personne odieuse SMA fecha a porta da comunicação da projecção. É possível que esta última tenha prosseguido, mas somente através do sentido psíquico. Porém, não com recurso ao meio literário. Depois deste fim a sua paixão entra no terreno da imaginação silenciosa, da memória associativa ou na existência fantasmática da mais pura autopoiesis psíquica. Esta nova re-entrada da paixão, a paixão no domínio da verdade psíquica, coincide com a decisão final de se devotar inteiramente a Deus. A conclusão de que a sua paixão é mais importante que o seu objecto abre o seu sujeito para a significação religiosa do desejo. É a paixão e o desejo de paixão e não o objecto em si que formam o essencial da experiência psíquica de SMA. Aqui se adquire a significação máxima

${ }^{43}$ Idem, Ibid., pp. 137-138. 
da vivência psíquica num sistema do pensamento puro, sem objectos, sem meio-ambiente. A paixão pura representa também auto-afecção pura.

A sua consciência de não poder ser mulher no sentido simbólico de esposa leva-a a passar ao sublime. O sistema religioso e o código da transcendência - imanência serve perfeitamente o propósito de designar a verdade psíquica do desejo absoluto frente a Deus, como recipiente absoluto. Ela está decidida a enfrentar para sempre a ausência das respostas factuais de Deus às projecções das suas preces no claustrum consagrado, na nova fraternidade das que se Lhe devotaram.

A outra possibilidade implícita no segundo desdobramento do autor, que inicialmente assinalei, leva a tomar as "Cartas Portuguesas" como paródia libertina sobre o desejo das mulheres. Mas, para a validar precisamos da presunção do autor empírico como sujeito masculino, aristocrata e mundano, o que implica ainda uma outra narrativa: aquela que, cancelando provisoriamente os efeitos comunicativos da identificação projectiva da forma epistolar destas Cartas, nos revela um observador de segundo grau da paixão como seu autor real.

\section{REFERÊNCIAS SUMÁRIAS}

(Soror Mariana Alcoforado) Lettres Portugaises traduites en François, Troisième Édition, à Paris, chez Claude Barbin, 1672.

D. BAECKER, Form und Formen der Kommunikation, Frankfurt / M., 2005.

W. R. Bion, "Attacks on Linking" in E. B. Spillius, Melanie Klein Today. Developments in Theory and Practice, vol. 1, Mainly Theory, op. cit., pp. 84-98 (tradução portuguesa - E. B. Spillius (ed.), Melanie Klein Hoje, Rio de Janeiro, 1991, pp. 95-109).

J. BRAY, The Epistolary Novel: Representation of Consciousness, London, New York, 2003.

M. DE CERTEAU, Histoire et Psychanalyse entre Science et Fiction, Paris, 1987.

P. COLEMAN / J. Lewis / J. Kowalik (eds.), Representations of the Self from the Renaissance to Romanticism, Cambridge, 2000.

L. CORDEIRO, Soror Mariana, a Freira Portuguesa, 2a Edição, Lisboa, 1890.

C. G. DUBOIS, Le Baroque : Profondeurs de l'Apparence, Bordeaux, 1993.

S. FREUD, The Standard Edition of the Complete Works of Sigmund Freud (ed. J. Strachey, A. Freud, A. Strachey e A. Tyson), London, 1953 e ss.

Idem, Métapsychologie, (trad. franc. J. Laplanche / J. B. Pontalis) Paris, 1986. Idem, « La Théorie de la Libido et le Narcissisme » in Idem, Introduction à la Psychanalyse (trad. V. Jankélévitch) Paris, 1984, pp. 389-407. 
A. KIESERLING, Kommunikation unter Anwesenden. Studien über Interaktionssysteme, Frankfurt / M., 1999.

M. KLEIN, "Notes on some Schizoid Mechanisms" in Idem, Envy and Gratitude and Other Works 1946-1963, The Melanie Klein Trust, London, 1975 (trad. port., "Notas sobre alguns mecanismos esquizóides" in Idem, Inveja e Gratidão e outros Trabalhos 1946-1963, Rio de Janeiro, 1985, pp. 17-43).

Idem, “On Identification” in Idem, Ibid, (trad. port., Ibid., pp. 169-204).

J. LACAN, "Le Stade du Miroir comme formateur de la Fonction du Je - telle qu'elle nous est révélée dans l' expérience psychanalytique" in Écrits $I-I I$, Paris, 1966, 1971, tomo I, pp. 89-97.

Idem, Le Séminaire. Séminaire - Livre XVIII - D’un Discours qui ne serait pas du Semblant, Paris, 2007.

Idem, Le Séminaire. Séminaire - l’ Éthique de la Psychanalyse (1959-1960), Paris, 1986.

Idem, Le Séminaire. L'Identification 1961-1962, in: http://staferla.free.fr/S9/ S9\%20L'IDENTIFICATION.pdf

N. LUHMANN, Liebe als Passion - Zur Codierung von Intimität, Frankfurt / M. 1994.

Idem, "Sozialsystem Familie" In Idem, Soziologische Aufklärung Bd. 5 Konstruktivistische Perspektiven, Wiesbaden, 20094, pp. 189-209.

Idem, "Glück und Unglück der Kommunikation in Familien: Zur Genese von Pathologien" in Idem, Ibid., pp. 210-219.

Idem, Das Recht der Gesellschaft, Frankfurt / M., 1993.

Idem, Soziale Systeme. Grundriss einer allgemeinen Theorie, Frankfurt / M., 1984 (1987).

Idem, Die Gesellschaft der Gesellschaft, I-II, Frankfurt / M., 1997.

Idem, "Individuum, Individualität, Individualismus" in Idem, Gesellschaftsstruktur und Semantik. Studien zur Wissenssoziologie der modernen Gesellschaft, Bd. 3, Frankfurt / M., 1993, pp. 149-258.

Idem, "Einführende Bemerkungen zu einer Theorie symbolisch generalisierter Kommunikationsmedien" in Soziologische Aufklärung 2, Opladen, 1975, reed. 1982, pp. 170-192; reed. em Idem, Aufsätze und Reden, Stuttgart, 2001, pp. $31-75$.

Idem, "Wie ist Bewußtsein an Kommunikation beteiligt" in Idem, Ibid., pp. 111-136; see also Idem, Soziologische Aufklärung, 6. Die Soziologie und der Mensch, Wiesbaden, 2005, pp. 38-54.

Idem, "Frauen, Männer und Georges Spencer Brown" in U. Pasero / C. Weinbach, (Hrsg.), Gender Trouble, Frankfurt / M., 2003, pp. 15-62.

Idem, Liebe. Eine Übung, Frankfurt / M., 2008 (ed. póstuma por A. Kieserling).

D. MELTZER, The Claustrum. An Investigation of Claustrophobic Phenomena, London, 1992 (reed. 2008). 
T. H. OGDEN, Projective Identification and Psychotherapeutic Technique, New Jersey, 1982.

J. ORTEGA y Gasset, On Love: Aspects of a single Theme, (trad.), New York, 1957.

U. PASERO, "Gender, Individualität, Diversity" in U. Pasero / C. Weinbach, (Hrsg.), Gender Trouble, Frankfurt / M., 2003, pp. 105-124.

U. PASERO / C. Weinbach, (Hrsg.), Gender Trouble, Frankfurt / M., 2003.

J. B. PONTALIS, Après Freud, Paris, 1968.

E. BALSEMÃO Pires, "Sade's 'Delectatio Morosa' and the Erotic Sovereignty" in Revista Filosófica de Coimbra, no 34 (Coimbra 2008), pp. 427-460.

Idem, "Família e Intimidade - Aspectos da Semântica da Intimidade e a Individuação do Sujeito" in Revista Filosófica de Coimbra, n 35 (Coimbra 2009), pp. 71-134.

J. SANDLER, "The Concept of Projective Identification" in Idem (ed.), Projection, Identification, Projective Identification, London, 1989, (reed. 2004) pp. 13-26.

E. B. SPILLIUS, Melanie Klein Today. Developments in Theory and Practice, vol. 1, Mainly Theory, London, 1988.

C. WEINBACH, Systemtheorie und Gender: das Geschlecht im Netz der Systeme, Opladen, 2004. 